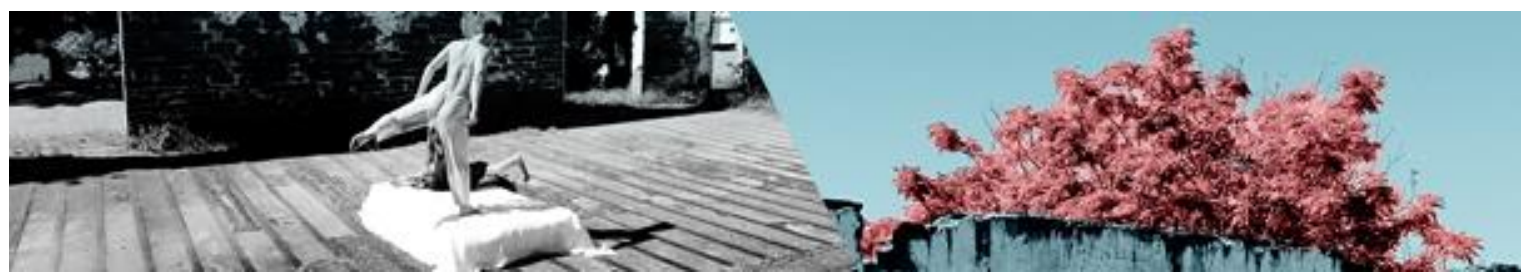

\title{
A ARTE/DANÇA COMO UMA DAS ARTES DA CENA NAS BASES, DOCUMENTOS E CURRÍCULOS NACIONAIS
}

Marcilio de Souza Vieira ${ }^{1}$

Resumo: Trata-se de uma pesquisa que reconhece a Dança como área de conhecimento. Busca-se, a partir dos documentos oficiais (Leis/LDBs, Resoluções, Minutas, Diretrizes, Parâmetros Curriculares), obter uma compreensão de como essa linguagem da arte foi se constituindo na educação brasileira a partir da LDB no 9394/96. Nessa perspectiva a proposta problematiza como objeto de investigação a evolução do pensamento pedagógico brasileiro do ensino de dança, na educação básica, em especial no Ensino Fundamental, a partir da identificação, classificação e periodização de tal ensino nos documentos oficiais. Objetiva-se, com a pesquisa, compreender como se constituiu o ensino da Dança no Brasil a partir dos documentos oficiais, e quais avanços e retrocessos dessa área de conhecimento a partir de tais documentos. A metodologia proposta baseiase no princípio da atualidade da pesquisa histórica que provoca o impulso investigativo e a necessidade de responder questões que interpelam-se na realidade presente. O método, obviamente, é de caráter historiográfico a partir da Nova História.

Palavras-chave: Dança; Educação; História/Memória; Ensino Fundamental.

\section{ART / DANCE AS ONE OF THE ARTS OF THE SCENE IN NATIONAL BASES, DOCUMENTS AND CURRICULA}

\begin{abstract}
It is a research that recognizes Dance as an area of knowledge. It is sought from the official documents (Laws/LDBs, Resolutions, Minutes, Guidelines, Curricular Parameters) to have an understanding of how this language of art was being constituted in Brazilian education from LDB $n^{\circ}$ 9394/96. In this perspective, the proposal problematizes as an object of research the evolution of Brazilian pedagogical thinking in dance education, in basic education, especially in Elementary Education, based on the identification, classification and periodization of such teaching in official documents. The objective of the research is to understand how the teaching of Dance in Brazil was constituted from the official documents and what advances and setbacks of this area of knowledge from such documents. The proposed methodology is based on the current tenet of historical research that provokes the investigative impulse and the need to answer questions that are questioned in the present reality. The method, of course, is historiographical in character from the New History.
\end{abstract}

Keywords: Dance; Education; History / Memory; Elementary School.

\section{L'ART / LA DANSE COMME L'UN DES ARTS DE LA SCÈNE DANS LES BASES, DOCUMENTS ET PROGRAMMES NATIONAUX}

Résumé: C'est une recherche qui reconnaît la danse comme domaine de connaissance. Rechercher des des documents officiels (lois/LDB, résolutions, procès-verbaux, lignes directrices, les programmes de normalisation) ont une bonne compréhension de la façon dont cette langue de l'art a été constitué

\footnotetext{
${ }^{1}$ Marcilio de Souza Vieira - Artista da Cena, Pós-Doutor em Artes, Doutor em Educação, Professor do Curso de Dança e dos Programas de Pós-Graduação PPGArC e PROFARTES da UFRN. Membro pesquisador do Grupo de Pesquisa em Corpo, Dança e Processos de Criação (CIRANDAR) e do Grupo de Pesquisa Corpo, Fenomenologia e Movimento (Grupo Estesia/UFRN).
}

VIEIRA, Marcilio de Souza. A arte/dança como uma das artes da cena nas bases, documentos e currículos nacionais. Revista da FUNDARTE, Montenegro, p.175-200, ano 19, no 37, Janeiro/Março. Disponível em: http://.seer.fundarte.rs.gov.br/index.php/RevistadaFundarte/index> 30 de março de 2019 


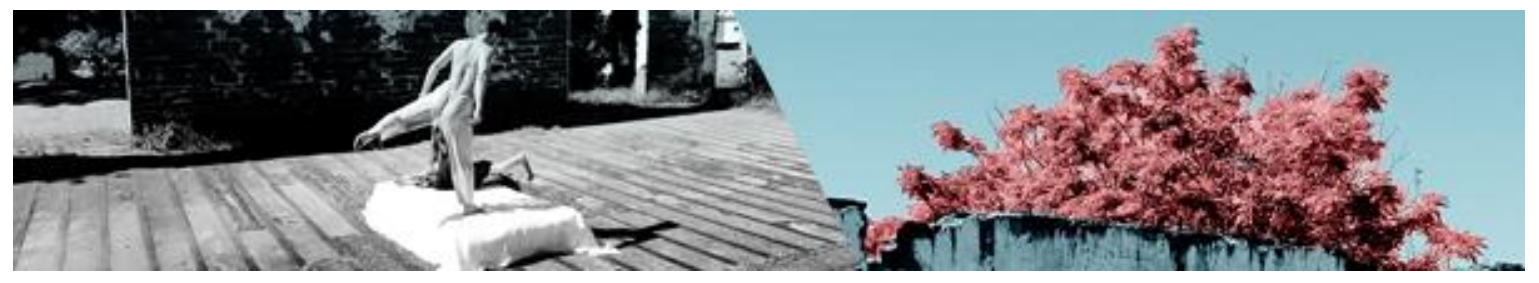

dans l'éducation brésilienne de la LDB 9394/96. Dans cette perspective, la proposition explique comment la recherche objet l'évolution de la pensée pédagogique brésilienne de l'éducation de la danse, l'éducation de base, en particulier à l'école primaire, de l'identification, la classification et la périodisation de cet enseignement dans les documents officiels. L'objectif de la recherche est de comprendre comment l'enseignement de la danse au Brésil a été constitué à partir des documents officiels et quels progrès et reculs de ce domaine de connaissances à partir de ces documents. La méthodologie proposée est basée sur le principe actuel de la recherche historique qui provoque l'impulsion d'investigation et la nécessité de répondre à des questions qui sont remises en question dans la réalité actuelle. La méthode, bien sûr, est historiographique par rapport à la Nouvelle Histoire.

Mots-clés: Danse; Éducation; Histoire / Mémoire; École primaire.

Ainda que a Dança esteja em um processo de consolidação, tanto como área do conhecimento, quanto seu espaço de atuação no meio educativo, é pertinente observar seu desenvolvimento, a partir dos documentos oficiais que a institucionaliza a fim de colaborar e avançar na sistematização de seu ensino. Ao analisar os registros históricos sobre o sistema de ensino brasileiro, é possível observar as trajetórias e desvios que a Arte, em suas diferentes linguagens, e o que os artistas/educadores tiveram que trilhar para conquistar o espaço de atuação no ambiente escolar.

Observando que a Dança é uma destas linguagens de Arte, percebe-se que as diferenças são relativas em relação ao caminho que tem sido percorrido para chegar às escolas brasileiras como Arte. O tempo é o diferencial, visto que algumas delas conseguiram se firmar mais rapidamente.

O escrito desse material ${ }^{2}$ trata-se de uma pesquisa que reconhece a Dança como área de conhecimento e busca, a partir dos documentos oficiais (Leis/LDBs, Resoluções, Minutas, Diretrizes Nacionais, Parâmetros Curriculares), ter uma compreensão de como essa linguagem da arte foi se constituindo na educação brasileira. Nessa perspectiva o estudo problematiza como objeto de investigação a evolução do pensamento pedagógico brasileiro do ensino de dança, na educação básica, em especial no Ensino Fundamental, a partir da identificação, classificação e periodização de tal ensino nos documentos oficiais.

\footnotetext{
${ }^{2}$ Essa escrita faz parte do Estágio Pós-Doutoral do pesquisador que foi desenvolvido no Programa de Pós-Graduação em Educação da UFPB e desenvolvida no Grupo de Estudos e Pesquisas "História, Sociedade e Educação no Brasil" - HISTEDBR-GT/PB, vinculado a Linha de Pesquisa História da Educação.
}

VIEIRA, Marcilio de Souza. A arte/dança como uma das artes da cena nas bases, documentos e currículos nacionais. Revista da FUNDARTE, Montenegro, p.175-200, ano 19, ํㅡ 37, Janeiro/Março. Disponível em: http://.seer.fundarte.rs.gov.br/index.php/RevistadaFundarte/index> 30 de março de 2019 


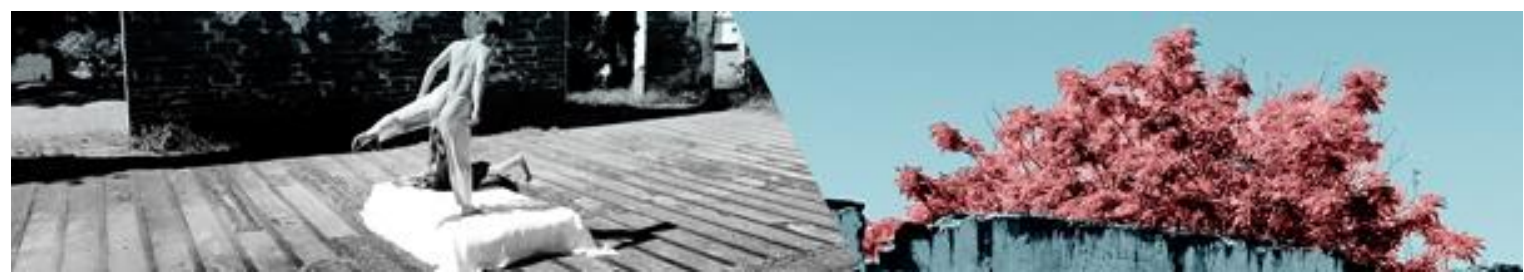

Trata-se de uma história que precisa ser também história do tempo da dança presente: ela deve abandonar qualquer veleidade a respeito de um interdito acerca do objeto próximo, tal como formulado pelos historiadores antigos, que protestavam em defesa de uma pretensa isenção do historiador, possível no seu entender apenas quando havia uma distância temporal em relação ao campo de estudos. É preciso desfazer a mitologia do olhar isento e indicar o sentido e a intenção do olhar do estudioso em/da Dança.

A pesquisa se identifica com o que se tem chamado de Nova História, isto é, uma nova forma de visualizar a história escrita. Diferente do paradigma tradicional de fazer história, que pode ser visto como uma visão do senso comum, influenciada mais pela política nacional e internacional do que local, e por uma visão de cima de grandes homens e grandes feitos, a Nova História considera o olhar particular. $\mathrm{Na}$ história tradicional os documentos são geralmente registros oficiais que expressam o ponto de vista oficial, e a grande ênfase na objetividade vem sempre embebida de preconcepções associadas à cor, ao credo, a classe ou ao sexo. A Nova História propõe que, ao invés de ver este paradigma como a maneira de se fazer história, este deve ser percebido como uma dentre várias abordagens percebidas possíveis do passado. Sendo assim, esta pesquisa quer informar futuras gerações sobre a história das ideias da dança na educação brasileira. Não busca estabelecer a verdade absoluta ou esgotar tudo sobre determinado assunto, apenas organizar dados de forma a oferecer ao leitor um ponto de vista.

A pesquisa objetiva-se pela necessidade de compreender como se constituiu o ensino da Dança no Brasil a partir dos documentos oficiais, e quais foram os avanços e os retrocessos dessa área de conhecimento a partir de tais documentos. A metodologia proposta baseia-se no princípio da atualidade da pesquisa histórica que provoca o impulso investigativo e a necessidade de responder questões que se interpelam na realidade presente. O método, obviamente, é de caráter historiográfico a partir da Nova História. Foi utilizada como tipologia de tais concepções dessas histórias das ideias do ensino da Dança brasileira as técnicas de manipulação, análise e interpretação de documentos, próprias da historiografia, cujos conteúdos serão confrontados com os determinantes histórico-sociais, visando evidenciar uma 


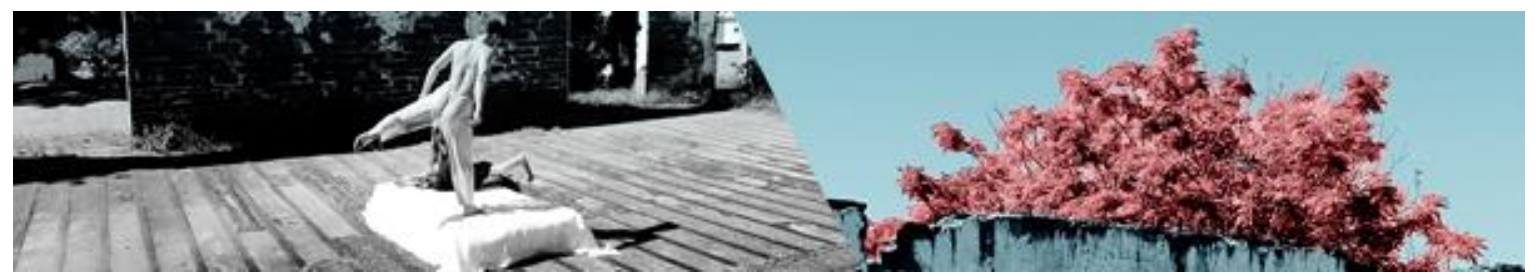

reflexão crítica dessas ideias do ensino da Dança na Educação Básica, em particular no Ensino Fundamental.

Desde as primeiras discussões acerca da obrigatoriedade do ensino de Arte nas escolas, sob a inclusão na LDB e suas modificações, a Dança é incluída como linguagem da Arte no volume seis dos Parâmetros Curriculares Nacionais - Arte. Só em 1997, no interior dos Parâmetros Curriculares Nacionais de Arte e de Educação Física, no caso da Dança, é que pela primeira vez na história brasileira, a dança vai ser apresentada como parte constitutiva da educação em Arte e em Educação Física. (Vieira, 2014)

Para entender como essa linguagem da Arte se constitui nos atuais documentos que norteiam a educação básica brasileira, se faz necessário, mesmo que de forma esparsa, contextualizar o ensino de Arte no Brasil, para compreender como este se organizou/organiza na atual conjuntura educacional. Nesse texto refletimos sobre a Arte/Dança no Ensino Fundamental e como esta a partir da Lei de Diretrizes e Bases no 9394/96 da educação brasileira vem se configurando como área de conhecimento.

Quais os rumos que a Arte/Dança seguiu na educação brasileira a partir das Leis de Diretrizes e Bases? Na LDB de 1961, Lei o 4024/61, ela não figurou e o ensino de Arte de maneira geral aparecia timidamente. Tal componente curricular era tido como complementar e as escolas poderiam ou não aderir ao ensino de Artes ao currículo.

O texto da LDB no 4024/61 (Brasil, 1961) não define que as linguagens da Arte deveriam ser ensinadas no ensino primário e médio, ficando a suposição de que a Dança não era conteúdo, mesmo optativo, nas práticas educativas desse componente curricular. A Arte no contexto da citada LDB não era valorizada como uma disciplina na educação básica, mas, fora do âmbito escolar, ela se manifestava no meio social por meio da literatura, do cinema, da música, da dança e do teatro.

É importante citar que mesmo aparecendo timidamente nessa LDB, a Arte aparece com base na expressão e na liberdade de criação a partir do movimento escola novista liderado por Anísio Teixeira no Brasil e ele foi grande incentivador do 


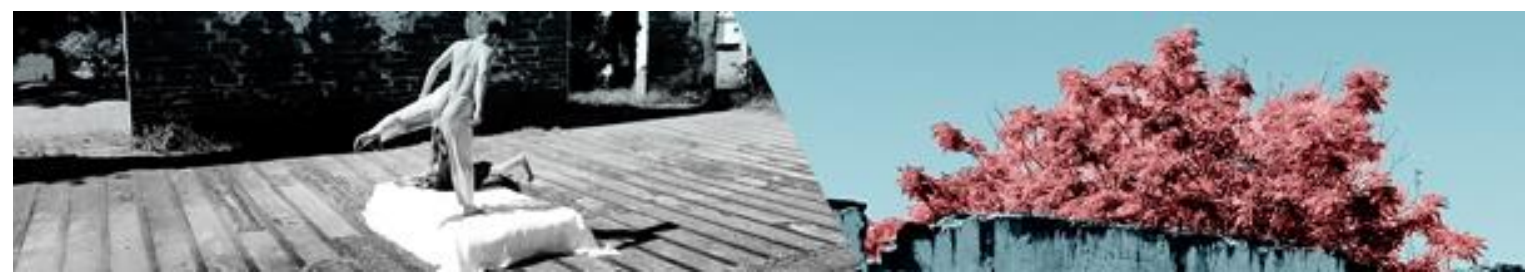

ensino da Arte para formação de professores nas escolas e um dos idealizadores do curso de Arte para formação de professores na Universidade de Brasília.

Convém citar que essa universidade deu a importância ao ensino de Arte que a LDB n. 4024/61 não ofereceu em seus artigos e parágrafos. Como assinala Correia (2007), verifica-se a pouca importância dada ao ensino da Arte nesse período, nas escolas de educação básica, fazendo-se questionar quais aspectos deveriam ser abordados na iniciação artística redigida na citada LDB, e dando destaque à Universidade de Brasília, por ter como característica um modelo de ensino humanista voltado para a arte e para a cultura.

Nesse sentido, de acordo com Barbosa (2002, p. 46), sobre a importância de tal ensino de Arte na citada universidade, destaca:

\begin{abstract}
A arte-educação ocupou um lugar relevante na Universidade de Brasília. Tencionava-se começar a Escola de Educação a partir de um Departamento de Arte-Educação. E, na realidade, a primeira entidade a estudar a educação organizada na Universidade de Brasília foi uma escola de arte para crianças e adolescentes. Sua organização envolveu durante quase um ano o trabalho de diferentes especialistas (arte-educadores, arquitetos, psicólogos, artistas, educadores, químicos, etc.) Pretendia-se começar as pesquisas e estudos de educação através da arte-educação, refletindo uma abordagem fiel à ideia de "educação através da arte".
\end{abstract}

No entanto, a presença da Arte no currículo escolar da educação básica, de acordo com a LDB n. 4024/61, tem sido marcada pela indefinição, ambiguidade e multiplicidade, levando a questionar quais linguagens artísticas deveriam ser ensinadas no âmbito da escola. Tal questionamento perdurou-se na Lei de Diretrizes e Bases seguinte, Lei ํㅜ 5692/71 que, embora tenha tornado o ensino de Arte denominado de Educação Artística como componente obrigatório, não definia quais linguagens deveriam ser ensinadas ao longo da educação básica.

Considerada apenas uma "atividade educativa" e não uma disciplina no currículo escolar, embora tenha sido incluída na Lei no. 5.692 (Brasil, 1971) com o título de Educação Artística, foi um avanço, tanto pelo aspecto de sustentação legal para esta prática, quanto por ter sido considerada importante na formação dos

VIEIRA, Marcilio de Souza. A arte/dança como uma das artes da cena nas bases, documentos e currículos nacionais. Revista da FUNDARTE, Montenegro, p.175-200, ano 19, no 37, Janeiro/Março. Disponível em: http://.seer.fundarte.rs.gov.br/index.php/RevistadaFundarte/index> 30 de março de 2019 


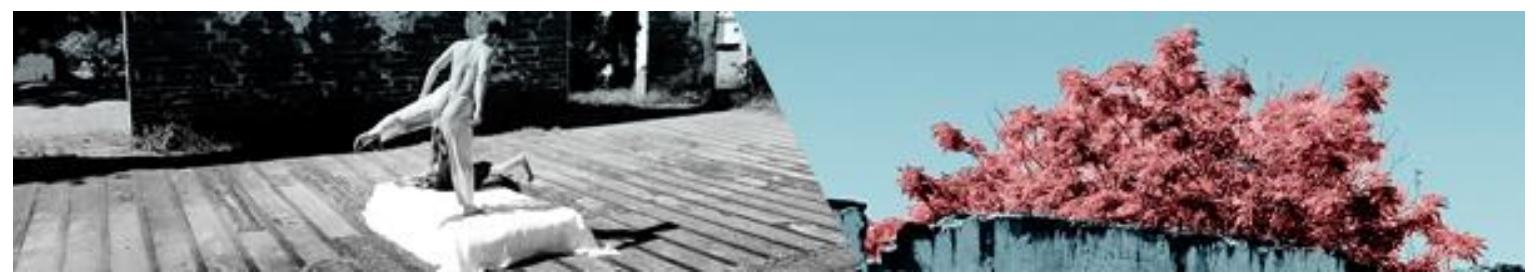

indivíduos. Porém, essa alteração criou questões novas a serem enfrentadas, principalmente para os professores de cada uma das linguagens artísticas.

Assim, na educação básica de acordo com a Lei, as séries iniciais do ensino de $1^{\circ}$ grau (1 $1^{a}$ a $4^{a}$ séries), o currículo pleno deveria ser organizado por atividades, sendo a educação geral tarefa exclusiva no ensino primário (art. 5ำ $§ 1^{\circ}$; Brasil, 1971, p.60). O parecer no 853/71 e a resolução no 8/71, do CFE, são os desdobramentos mais importantes da Lei 5.692/71, pois definem o núcleo comum do currículo. A resolução esclarece, no artigo $4^{\circ} \S 1^{\circ}$, que "[...] nas atividades, a aprendizagem far-se-á principalmente mediante experiências vividas pelo próprio educando no sentido de que atinja, gradativamente, a sistematização de conhecimentos" (Idem, p.400).

Além das matérias obrigatórias do núcleo comum, a organização da matriz curricular completava-se com as disciplinas obrigatórias previstas no artigo $7^{\circ}$ da Lei 5.692/71, que correspondiam às antigas práticas educativas da Lei 4.024/61 e ao ensino de Artes nominado de Educação Artística, de matrícula facultativa, mas que deveria ser oferecida pela escola.

Assim, sob a designação de Educação Artística, o ensino de Arte foi contemplado no próprio corpo da Lei, enquanto que, comparativamente, a definição das matérias do "núcleo comum, obrigatório em âmbito nacional", ficou a cargo do Conselho Federal de Educação da Lei 5.692/71, Art. 4ํ․ (Brasil, 1971).

Após esta Lei, os professores de Desenho, Música, Trabalhos Manuais, Canto Coral e Artes Aplicadas, que utilizavam para as aulas os conhecimentos específicos de suas linguagens, passaram a ver esses saberes transformados em "atividades artísticas", o que fica claro na análise do Parecer n 540/77 do Conselho Federal de Educação (Brasil, 1977): “[...] não é uma matéria, mas uma área bastante generosa e sem contornos fixos, flutuando ao sabor das tendências e dos interesses". Segundo Fusari e Ferraz (2001), os professores das escolas públicas encontraram dificuldades em apreender métodos de ensino nas salas de aula, resultando numa prática pouco ou nada fundamentada, necessitada de aprofundamentos teórico-metodológicos.

VIEIRA, Marcilio de Souza. A arte/dança como uma das artes da cena nas bases, documentos e currículos nacionais. Revista da FUNDARTE, Montenegro, p.175-200, ano 19, nº 37, Janeiro/Março. Disponível em: http://.seer.fundarte.rs.gov.br/index.php/RevistadaFundarte/index> 30 de março de 2019 


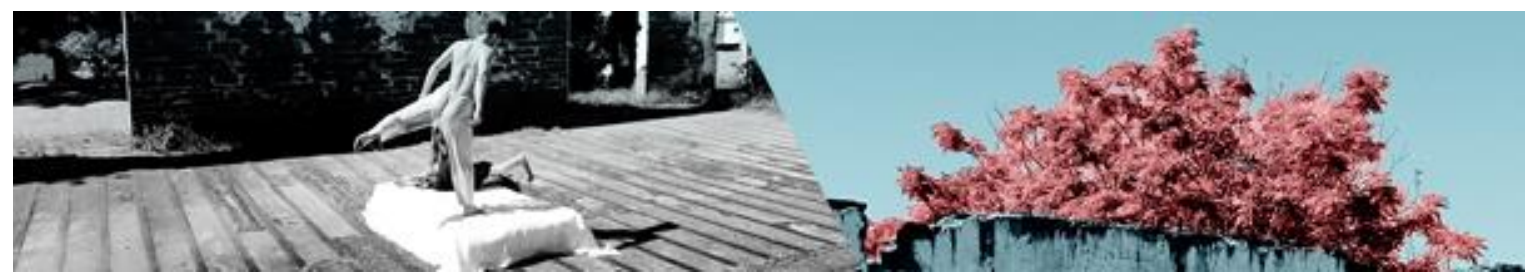

O fato de a LDB de 1971 estipular a implantação de uma disciplina tão ampla no ensino regular ocasionou a busca pela formação, o quanto mais rápida, de profissionais para atuarem nessa área. Isso desencadeou uma série de tentativas de formação de professores em grande escala, sem antecedentes, o que causou grandes críticas pelos profissionais da época. Observa-se que o Programa de Desenvolvimento Integrado de Arte Educação (PRODIARTE) foi uma tentativa de se inserir a Educação Artística nas escolas, assim como os cursos de graduação de licenciatura curta, os cursos rápidos e as parcerias com a Escolinha de Arte do Brasil (EAB).

A Educação Artística, compreendida como atividade polivalente, desarticulou o ensino da Dança em si, pois esta perdeu sua identidade dentro da realidade escolar. A partir da não-obrigatoriedade do ensino dessa linguagem artística, as escolas não se preocuparam em inserir profissionais especializados para tal ensino, o que restringiu seu ensino a escolas especializadas, elitizando-se, assim, o acesso ao ensino da Dança. Essa manifestação artística, assim como o teatro, também ficou à parte da Educação Artística, pois ocupara papel apenas nas festas comemorativas e nas atividades recreativas, visto que a ênfase desta disciplina passou a ser nas artes plásticas.

Quais linguagens artísticas foram contempladas pelo componente curricular designado como Educação Artística? Isso não é definido com clareza pelo uso da expressão no texto da Lei, embora, aos poucos, através de pareceres e resoluções do Conselho Federal de Educação (CFE), assim como da prática escolar, vai sendo demarcado o campo da Educação Artística.

Cabe mencionar aqui que no âmbito da aplicação dos pressupostos teórico metodológicos da Lei ํㅜ 5692/71, a Dança aparece tematizada juntamente com o Teatro como atividades artísticas com fins terapêuticos e educativos ou como apêndice para outros componentes curriculares. E desta maneira, as técnicas de trabalho artístico eram voltadas para desenvolvimento de atividades com fins de recreação, lazer ou ainda apoio para as demais disciplinas do currículo, reforçando os seus conteúdos. Eram atividades isoladas com o caráter de trabalhar o fazer por 


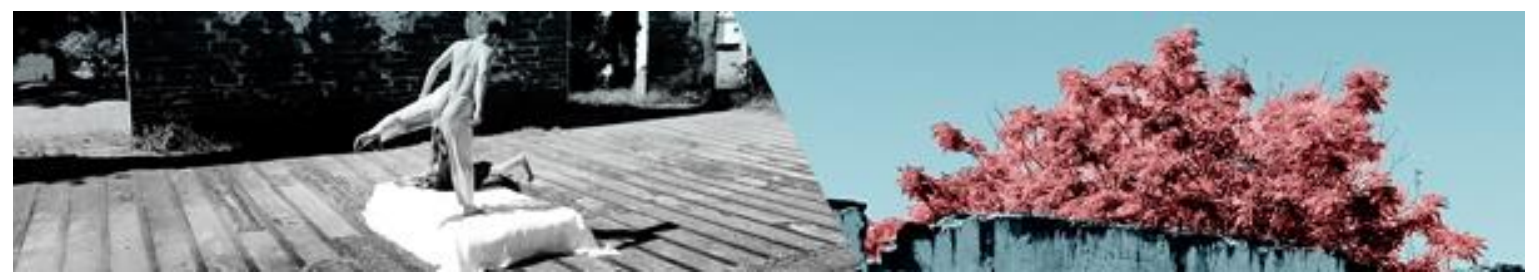

meio de aulas com temas, ou simplesmente com o desenvolvimento de técnicas artísticas.

O ensino de Arte na Educação Básica, outrora designado como atividade e denominado por Educação Artística por meio da Lei 5692/71, tornou-se um componente curricular obrigatório, com a Lei 9396/96. Essa Lei também foi responsável por dividir o ensino brasileiro em dois níveis: A Educação Básica que inclui a Educação Infantil (creche e pré-escola), o Ensino Fundamental e o Ensino Médio, além da Educação de Jovens e Adultos e da Educação Profissional; e o Ensino Superior.

A Lei n. 9.394/96 (Brasil, 1996), em seu Art. 26, parágrafo 2, estabeleceu que "[...] o ensino da Arte, especialmente em suas expressões regionais, constituirá componente obrigatório nos diversos níveis da educação básica, de forma a promover o desenvolvimento cultural dos alunos"; ela garante um espaço para as Artes na escola, como já era estabelecido na Lei anterior, com a inclusão da Educação Artística.

Assim, o ensino de Artes/Dança, de acordo com a Lei, é garantido na Educação Infantil, como preconiza seus referenciais, no Ensino Fundamental e no Ensino Médio, tal como exposto nos Parâmetros Curriculares Nacionais e Diretrizes Curriculares Nacionais, e também se constituiu no Ensino Superior e na Educação Profissional mesmo antecedendo a Lei n. 9.394/96.

Para garantir tal obrigatoriedade do ensino de Arte na educação básica foram criados documentos para a elaboração de currículos destinados ao Ensino Básico, a saber: Referencial Curricular Nacional para a Educação Infantil; Parâmetros Curriculares Nacionais Ensino Fundamental; e Parâmetros Curriculares Nacionais do Ensino Médio. Além desses documentos, diretrizes, resoluções, minutas foram sendo constituídas para garantir o ensino de Artes em suas quatro linguagens no espaço escolar, no entanto tais documentos não garantiram que as linguagens da Dança, do Teatro, da Música e das Artes Visuais fossem ofertadas na escola de forma satisfatória.

Contudo, com as mudanças e avanços no pensamento de Arte do país, ressalvadas as impressões generalizadas da área, os avanços da Lei e retificações currículos nacionais. Revista da FUNDARTE, Montenegro, p.175-200, ano 19, no 37, Janeiro/Março. Disponível em: http://.seer.fundarte.rs.gov.br/index.php/RevistadaFundarte/index> 30 de março de 2019 


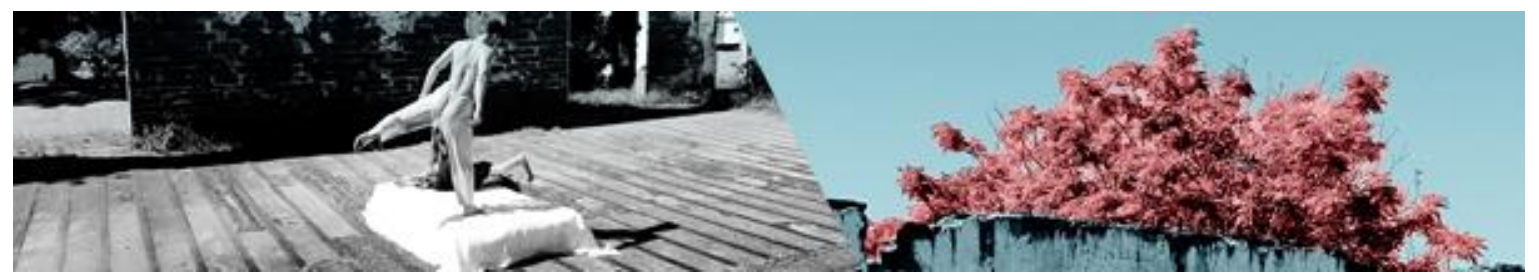

em sua redação, associados aos movimentos sociais encabeçados por associações de pesquisa, tais como a Federação de Arte Educadores do Brasil (FAEB), a Associação Brasileira de Educação Musical (ABEM), Associação Brasileira de Pesquisa e Pós-Graduação em Artes Cênicas (ABRACE), Associação Nacional de Pesquisa em Artes Plásticas (ANPAP) e Associação Nacional de Pesquisadores em Dança (ANDA), o ensino da Artes foi delineando seu espaço na educação básica brasileira.

Um exemplo exitoso dessas associações em relação ao ensino de Artes na educação básica foi a atualização da nomenclatura da área de Educação Artística para Artes em 2005, através do Parecer CNE/CEB n. 22/2005. Outrossim, o parecer ao atualizar a nomenclatura diz: "[...] Ficou, assim, pavimentado o caminho para se identificar a área por "Arte", não mais entendida como uma atividade, um mero "fazer por fazer", mas como uma forma de conhecimento" (Brasil, 2005, p. 2), com base na formação específica plena em uma das linguagens: Artes Visuais, Dança, Música e Teatro.

Ainda como êxito dessas associações para o fortalecimento da área, aconteceram a inclusão da Arte na Educação Infantil (Lei № 12.796, de 2013), a revisão do Art. $26, \S 2^{\circ}$, em que diz que o ensino da arte constituirá componente curricular obrigatório, nos diversos níveis da educação básica - e inclusão nesse parágrafo das expressões regionais (redação dada pela Lei no 12.287 , de 2010) de forma a promover o desenvolvimento cultural dos alunos - e após Medida Provisória $n^{\circ} 746$ de 2016 em que deixou de fora o ensino de Artes no Ensino Médio (redação dada pela Lei no 13.415, de 2017). (Brasil, 2017)

Nessa seara de êxitos, cita-se o detalhamento das áreas componentes da disciplina de Arte nos currículos escolares, instituído pela Lei № 13.278, de 2016, que regulamentou o assunto e concedeu prazo de cinco anos para a adequada formação de professores, em número suficiente para seu cumprimento. Após essa revisão, o texto do parágrafo citado ficou assim: "[...] § 6 : As artes visuais, a dança, a música e o teatro são as linguagens que constituirão o componente curricular de que trata o $§ 2^{\circ}$ deste artigo". (Brasil, 2016, S/P).

VIEIRA, Marcilio de Souza. A arte/dança como uma das artes da cena nas bases, documentos e currículos nacionais. Revista da FUNDARTE, Montenegro, p.175-200, ano 19, no 37, Janeiro/Março. Disponível em: http://.seer.fundarte.rs.gov.br/index.php/RevistadaFundarte/index> 30 de março de 2019 


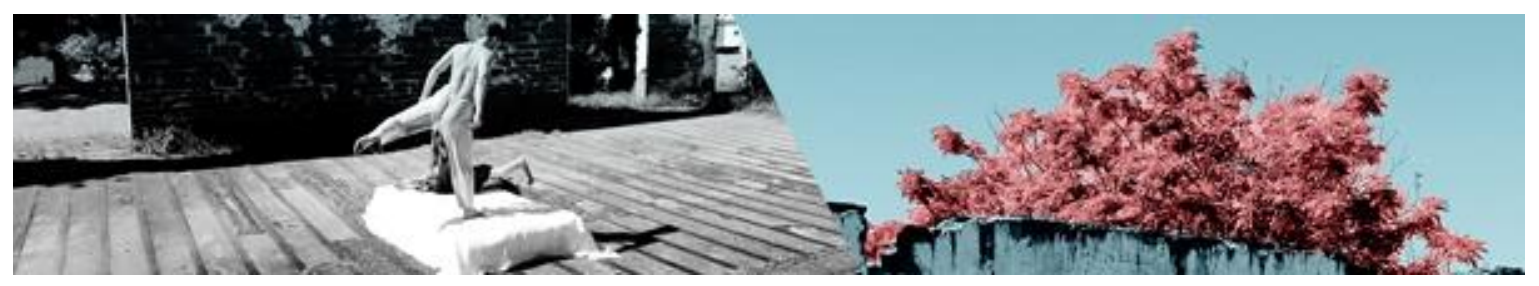

A partir da LDB de 1996, foi garantido um espaço para a Arte/Dança no âmbito escolar, mesmo que essa garantia tenha se dado nos documentos que norteiam a educação brasileira. Da LDB citada outros desdobramentos foram necessários para que as Artes se configurassem como área de conhecimento, e não mais como apêndice para os outros componentes curriculares no espaço escolar tidos como nobres. Dessa forma, quais os novos rumos, quais os documentos que nortearam essa inserção da Arte/Dança na escola?

A produção de ideias sobre o currículo no Brasil avançou substancialmente com a LDB no 9394/96, e nesse sentido, o poder público assumiu seu papel com a publicação em 1998 dos Parâmetros Curriculares Nacionais (PCN), que foram reformulados em 2010 pelas Diretrizes Curriculares Nacionais (DCN).

As Diretrizes da Educação Básica visam integrar as três etapas sequentes desse nível da escolarização (Educação infantil, Ensino Fundamental, Ensino Médio) em um único todo dentro dos sistemas federal, estaduais, distrital e municipais, propondo princípios de organicidade, sequencialidade e articulação para a formação dos alunos, que são considerados a partir de sua dimensão humana de sujeitos concretos, integrados ao meio ambiente físico e ao contexto histórico e cultural da sociedade, com suas condições corporais, emocionais e intelectuais.

Para tanto, essas Diretrizes entendem o currículo em termos de duas partes fundamentais e interdependentes, a primeira delas voltada para a formação básica comum dos alunos e a outra para a formação geral diversificada. A base nacional comum definida pela LDB de 1996 compreende a Língua portuguesa, a Matemática, as Ciências naturais e sociais com a inclusão nessa última de estudos sobre a história e cultura afro-brasileira e indígena, a Arte em suas diferentes linguagens artísticas, a Educação física e o Ensino religioso, que nas palavras das Diretrizes são saberes "[...] gerados nas instituições produtoras do conhecimento científico e tecnológico; no mundo do trabalho; no desenvolvimento das linguagens; nas atividades desportivas e corporais; na produção artística; nas formas diversas e exercício da cidadania; nos movimentos sociais, [...]" (Brasil, 2012, p. 31-2).

Qual o lugar reservado a Artes/Dança na Base Nacional Comum Curricular? Com esse questionamento introduzo os desafios e as possibilidades dessa base

VIEIRA, Marcilio de Souza. A arte/dança como uma das artes da cena nas bases, documentos e currículos nacionais. Revista da FUNDARTE, Montenegro, p.175-200, ano 19, ํㅜ 37, Janeiro/Março. Disponível em: http://.seer.fundarte.rs.gov.br/index.php/RevistadaFundarte/index> 30 de março de 2019 


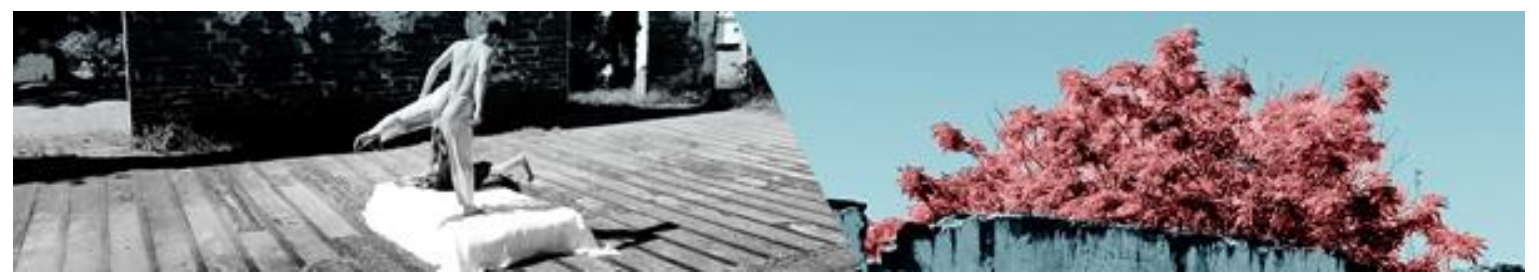

para o componente curricular em tela e suas problemáticas reveladas. Esse documento que organiza a educação básica brasileira teve três versões e consultas públicas para sua gestação e disseminação nos estados do país para que este tenha uma base comum curricular nacional.

Deve-se lembrar que essa não é uma discussão nova, uma vez que a Constituição Brasileira de 1988 já sinalizava em seu Art. 210 indicação da fixação de "[...] conteúdos mínimos para o ensino fundamental, de maneira a assegurar formação básica comum e o respeito aos valores culturais e artísticos, nacionais e regionais" (Brasil, 1988, Art. 210), discussão retomada na LDB ํo 9394/96 que destaca que as instituições de ensino elaborem os seus currículos para a Educação Infantil, o Ensino Fundamental e Ensino Médio a partir da base comum nacional, mas respeitando suas características regionais, culturais, sociais e econômicas, o que a Lei chama de parte diversificada, cuja função é contextualizar o ensino em situações específicas.

Desde sua primeira versão até a última, as discussões giraram em torno do currículo comum para atender a educação básica brasileira, no que concerne aos ensinos infantil e fundamental, uma vez que o Ensino Médio ficou de fora da última versão elaborada, por não se ter um entendimento de como se deveria organizar tal currículo para essa última etapa da educação básica, em especial para o ensino de Artes.

De acordo com o Ministério da Educação tratou-se de um documento que refletiu e contemplou diferentes posicionamentos, visto que texto-base foi preparado por uma equipe de especialistas de diversificadas universidades do país, sistemas de ensino e entidades como a exemplo da UNDIME, num trabalho gerido por equipes e assessores ligados ao Ministério da Educação. Assim, o arcabouço preliminar para a elaboração da BNCC foi constituído conforme os esquemas a seguir:

VIEIRA, Marcilio de Souza. A arte/dança como uma das artes da cena nas bases, documentos e currículos nacionais. Revista da FUNDARTE, Montenegro, p.175-200, ano 19, nº 37, Janeiro/Março. Disponível em: http://.seer.fundarte.rs.gov.br/index.php/RevistadaFundarte/index> 30 de março de 2019 


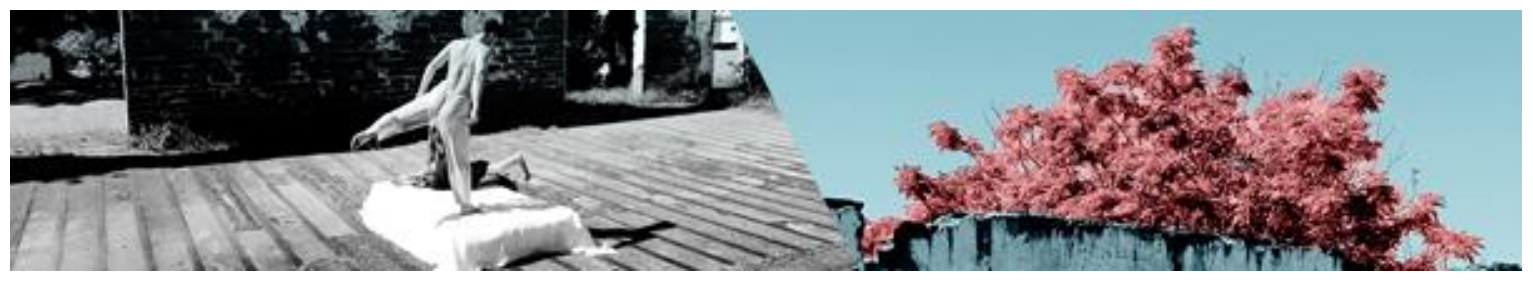

Orientação Normativa da Base Nacional Comum

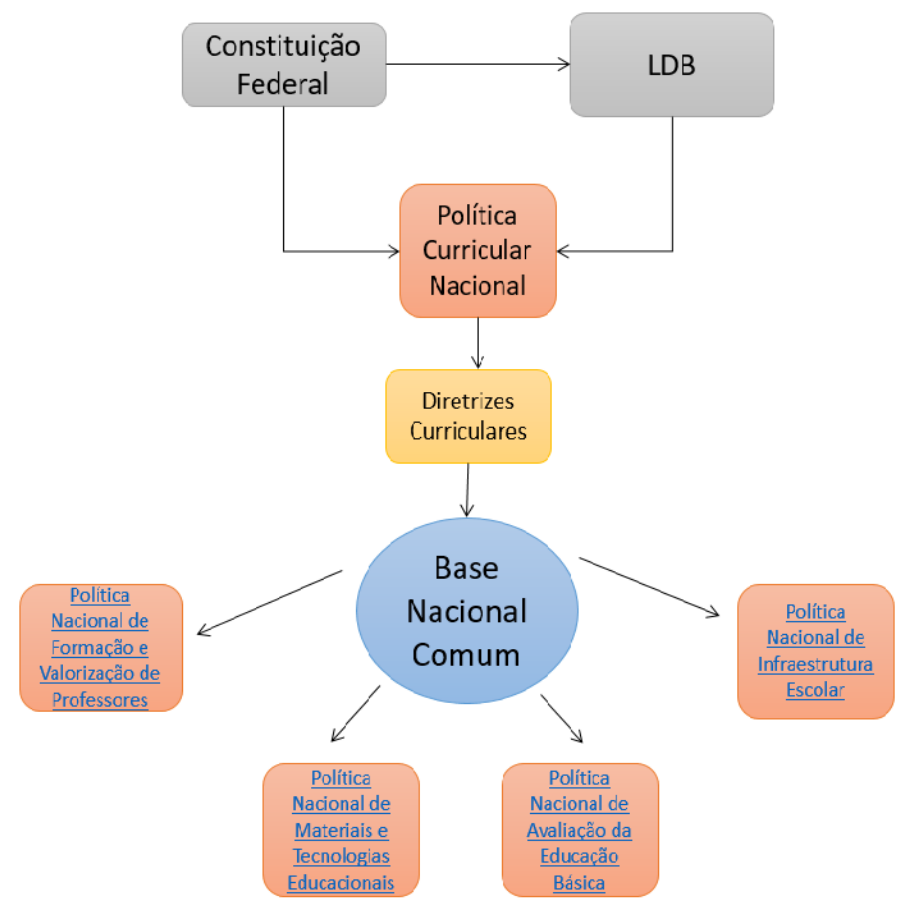

Fonte: BNCC. Disponível em http://basenacionalcomum.mec.gov.br/

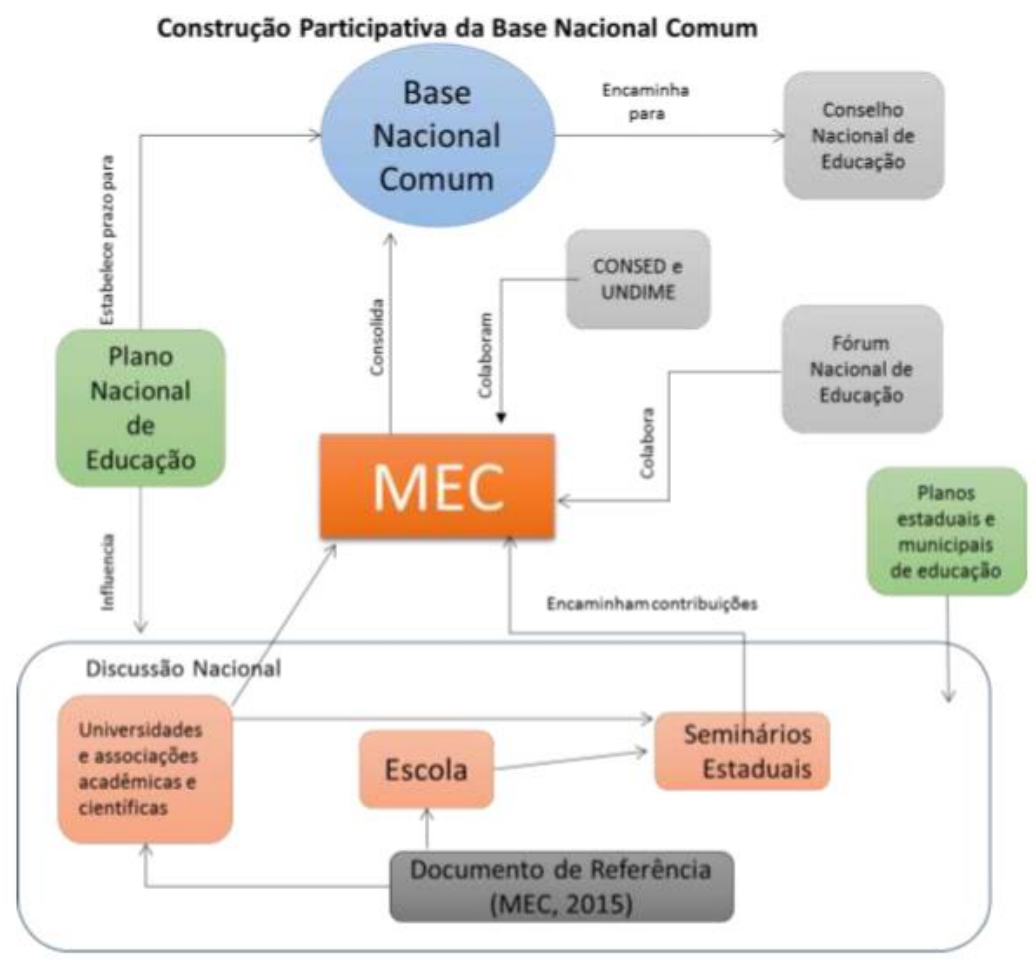

Fonte: BNCC. Disponível em http://basenacionalcomum.mec.gov.br/

VIEIRA, Marcilio de Souza. A arte/dança como uma das artes da cena nas bases, documentos e currículos nacionais. Revista da FUNDARTE, Montenegro, p.175-200, ano 19, no 37, Janeiro/Março. Disponível em: http://.seer.fundarte.rs.gov.br/index.php/RevistadaFundarte/index> 30 de março de 2019 


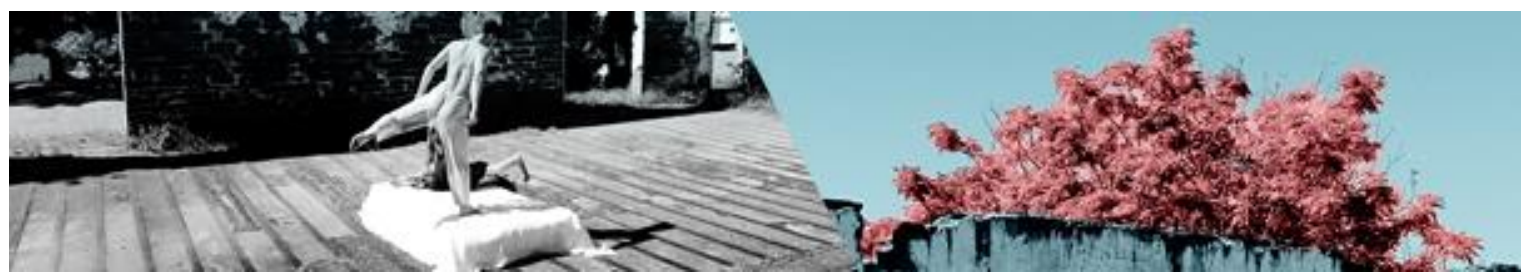

A partir da dinâmica exposta no esquema, o MEC consolidou o documento preliminar que foi publicado no dia 15 de setembro de 2015 e, desde então, passou a ser submetido à consulta pública, que foi chamada de discussão nacional. Nessa consulta foram levados em consideração os ajustes, a mobilização, a discussão nacional e a consolidação da base, conforme esquema que se segue:

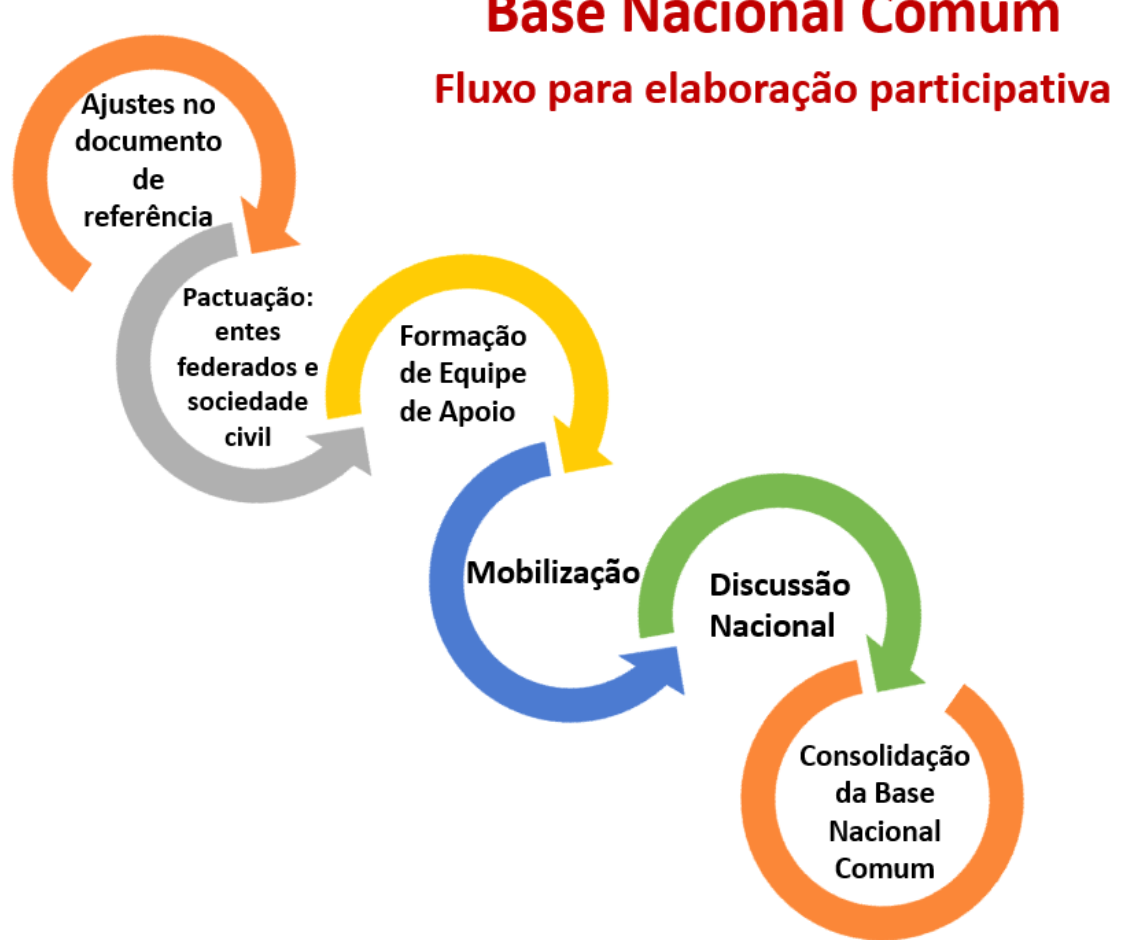

Fonte: BNCC. Disponível em http://basenacionalcomum.mec.gov.br/

E o ensino de Artes/Dança, qual o seu papel na Base Nacional Comum Curricular?

O Conselho Nacional de Educação em relação às Diretrizes Nacionais para a Educação Básica vai dizer que a Arte, em suas diferentes linguagens artísticas, se constitui como parte integrante da base nacional comum, no entanto, na crise revelada, esta área de conhecimento retroagiu empobrecendo o currículo e equiparando-se aos problemas não muito diferentes daqueles associados ao passado. Refletimos, dessa maneira, como o ensino de Artes/dança vem se configurando na educação brasileira a partir da Base Nacional Comum Curricular. currículos nacionais. Revista da FUNDARTE, Montenegro, p.175-200, ano 19, № 37, Janeiro/Março. Disponível em: http://.seer.fundarte.rs.gov.br/index.php/RevistadaFundarte/index> 30 de março de 2019 


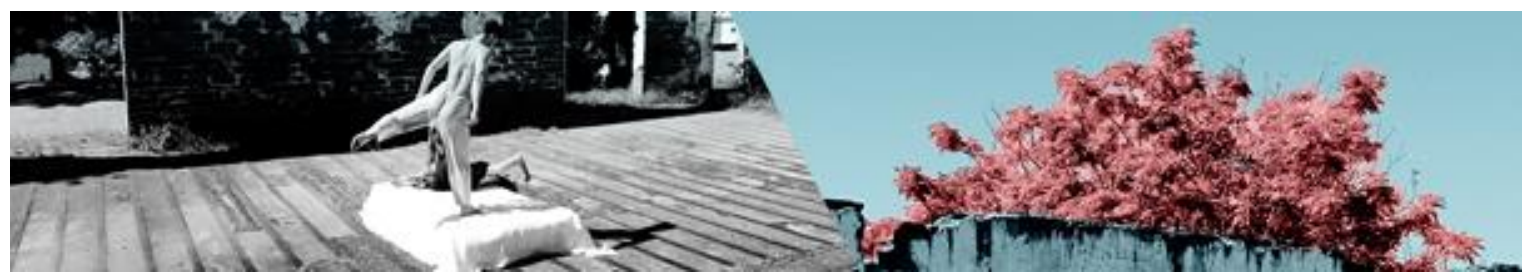

Em suas três versões, assim procede a BNCC para o ensino de Artes:

O componente curricular Arte engloba quatro diferentes subcomponentes: artes visuais, dança, teatro e música, bem como de suas práticas integradas (como, por exemplo, a performance, a instalação, a videoarte, o circo, a videodança, a ópera, etc.). Cada subcomponente tem seu próprio contexto, objeto e estatuto, constituindo-se em um campo que, ao mesmo tempo que compõem transdisciplinarmente a área da Arte, tem uma singularidade que exige abordagens específicas e especializadas. [...] (Brasil, 2015, p. 82)

O componente curricular Arte engloba quatro linguagens: Artes Visuais, Dança, Música e Teatro. Cada linguagem tem seu próprio campo epistemológico, seus elementos constitutivos e estatutos, com singularidades que exigem abordagens pedagógicas específicas das artes e, portanto, formação docente especializada. [...] (Brasil, 2016, p. 113)

A Arte é uma área do conhecimento e patrimônio histórico e cultural da humanidade. No Ensino Fundamental, o componente curricular está centrado em algumas de suas linguagens: as Artes visuais, a Dança, a Música e o Teatro. Essas linguagens articulam saberes referentes a produtos e fenômenos artísticos e envolvem as práticas de criar, ler, produzir, construir, exteriorizar e refletir sobre formas artísticas. [...] (Brasil, 2017, p. 151)

O surgimento da primeira versão da BNCC já se fez em meio a críticas identificando duas modalidades necessárias para o diálogo com a área de Artes: uma questiona sua necessidade, outra questiona os conteúdos apresentados e sugere modificações.

Outros agravantes se identificam na proposição de duas das versões, a saber:

Na Educação Básica a Arte se caracteriza por trabalhar o processo criativo em seus diferentes subcomponentes, englobando o fazer, o fruir e a reflexão sobre o fazer e o fruir. (Brasil, 2015, p. 82)

$\mathrm{Na}$ BNCC de Arte, cada uma das quatro linguagens do componente curricular - Artes visuais, Dança, Música e Teatro - constitui uma unidade temática que reúne objetos de conhecimento e habilidades articulados às seis dimensões apresentadas anteriormente. Além dessas, uma última unidade temática, Artes integradas, explora as relações e articulações entre as diferentes linguagens e suas práticas, inclusive aquelas possibilitadas pelo uso das novas tecnologias de informação e comunicação. (Brasil, 2017, p. 155)

VIEIRA, Marcilio de Souza. A arte/dança como uma das artes da cena nas bases, documentos e currículos nacionais. Revista da FUNDARTE, Montenegro, p.175-200, ano 19, ํㅜ 37, Janeiro/Março. Disponível em: http://seer.fundarte.rs.gov.br/index.php/RevistadaFundarte/index> 30 de março de 2019 


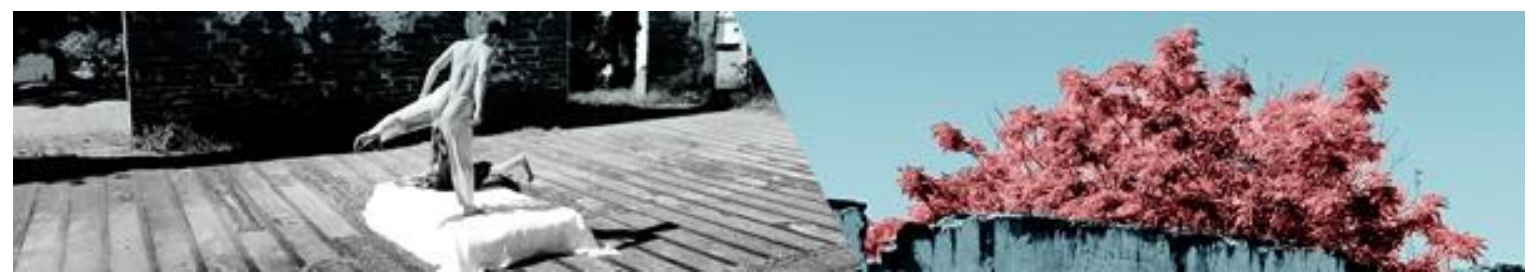

Nessas duas versões (primeira e terceira) o ensino de Artes é relegado a subcomponente e a unidade temática, favorecendo uma aprendizagem polivalente da área e negando a produção de conhecimento de cada uma das linguagens que o aluno da educação básica tem direito, e, ainda, contrariando o que preconiza a LDB de 1996, reforçada pelo Substitutivo da Câmara dos Deputados, que altera o parágrafo sexto do artigo 26 da LDB 9.394/96, que fixa as diretrizes e bases da educação nacional, referente ao ensino da Arte sobre a obrigatoriedade das quatro linguagens e seu reconhecimento como área que está em constante produção do conhecimento.

A Ementa do Substitutivo dispõe que as Artes Visuais, a Música, a Dança e o Teatro são as linguagens do componente curricular do ensino da Arte obrigatório, nos diversos níveis da educação básica que trata o parágrafo do artigo 26 da referida Lei. Apesar dessa grande conquista da especificação das linguagens artísticas, o componente curricular Arte não é posto como uma área de conhecimentos próprios na BNCC.

Considerando a distinção entre áreas de conhecimento e componentes curriculares, pode-se dizer que, em ambas as versões, o entendimento de Artes na educação básica é abrangente e polivalente. Apesar de pretender uma articulação entre os componentes curriculares por meio das áreas, estes são apresentados separadamente, o que, certamente, dificultará a sua articulação. Desse modo, a pretensa renovação e o aprimoramento ficarão dificultados, pois a organização da BNCC permite que a polivalência seja efetivada no componente curricular de Artes.

Verifica-se que na terceira versão da BNCC o foco da Arte na educação básica deve estar em práticas expressivas individualizadas, com ênfase no fazer e no fruir, desconsiderando a dimensão crítica e conceitual da Arte. A Arte possui conteúdo próprio que vai além da dimensão sensível. $A$ impressão que se tem é que há a tentativa de esvaziar o ensino de Arte do seu teor crítico e reflexivo, para formar sujeitos dóceis e conformados.

A diluição da Área Arte com suas diferentes linguagens artísticas na Área de Linguagem compromete a conquista da formação de professores de Arte em licenciaturas específicas, como ocorre na atualidade em diversas universidades, 


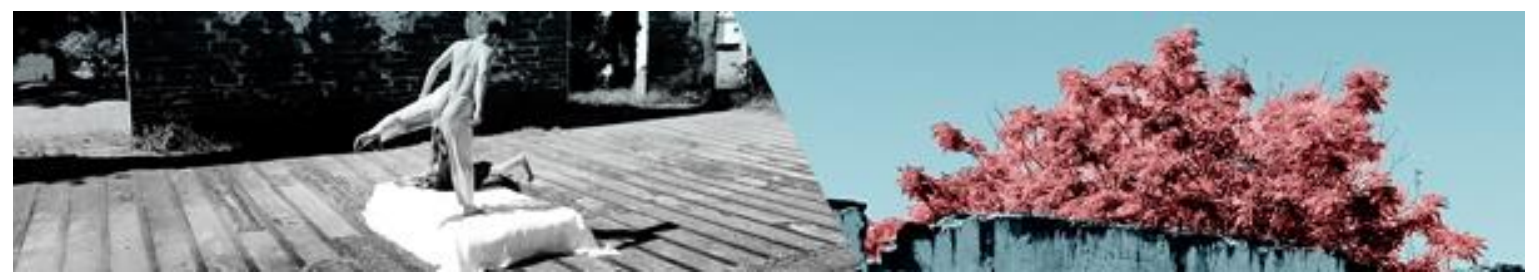

faculdades e centros universitários no nosso país, dando abertura para que profissionais licenciados em outras áreas possam lecionar Arte, como acontecia no período da ditadura militar. A limitação do espaço da Arte no currículo da Educação Básica é muito simbólica, pois demonstra, de forma clara, que existe a intenção de tolher o potencial do trabalho artístico na escola, perdendo espaço para áreas de conhecimento mais científicas. As Artes não terão espaço pleno em uma BNCC que reduz o docente a um eficiente disseminador de competências para obtenção de resultados "exitosos" nas avaliações. Não haverá espaço para as subjetividades, para a diversidade e para a criatividade tão necessária à ação docente.

Será a Arte/Dança considerada um conhecimento marginal no Ensino Fundamental da Educação Básica?

Após a publicação da terceira versão da BNCC o ensino de Artes passou a se constituir como uma unidade temática, como bem ratificado neste texto e escrito nesse documento que teve duas versões anteriores antes de ser promulgado como a base comum curricular para a educação básica do país.

As inquietações e as ponderações de pesquisadores da área parecem não terem sido ouvidas, tampouco se respeitou a LDB de 1996 e o Substitutivo da Câmara dos Deputados, que altera o parágrafo sexto do artigo 26 da LDB 9.394/96 quando afirma ser a Arte uma área de conhecimento.

Entidades ligadas ao ensino de Artes no país como a Federação de Arte Educadores do Brasil (FAEB), por meio de sua Confederação, a Associação Brasileira de Pesquisa e Pós-Graduação em Artes Cênicas (ABRACE), a Associação Nacional de Pesquisadores em Dança (ANDA), a Associação Nacional de Pesquisadores em Artes Plásticas (ANPAP) e a Associação Brasileira de Educação Musical (ABEM) manifestaram considerações acerca das três versões, das quais algumas dessas considerações importantes para a área não foram contempladas na versão final da BNCC.

Sobre a linguagem da Dança, assim se colocou as associações FAEB e ABRACE:

VIEIRA, Marcilio de Souza. A arte/dança como uma das artes da cena nas bases, documentos e currículos nacionais. Revista da FUNDARTE, Montenegro, p.175-200, ano 19, nº 37, Janeiro/Março. Disponível em: http://.seer.fundarte.rs.gov.br/index.php/RevistadaFundarte/index> 30 de março de 2019 


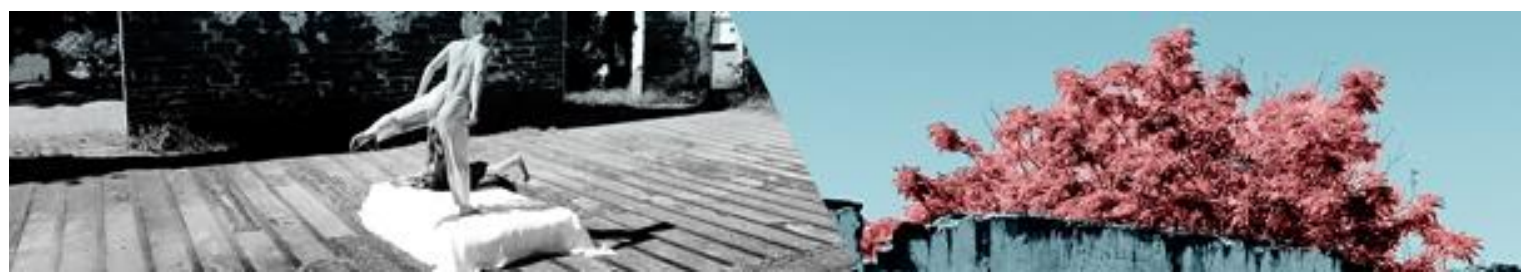

O campo de conhecimento artístico Dança aponta necessidades de um processo de ensino-aprendizagem que considere o corpo e o movimento em processos de criação e fruição artística. A Dança é um campo de conhecimento que apresenta conteúdos específicos a serem abordados em todos os anos da Educação Básica, levando em consideração os sujeitos, suas visões de mundo e suas diferenças sociais, históricas e culturais. 0 ensino da Dança está comprometido com uma formação alicerçada no conhecer, no fazer, no apreciar e no criticar, em grau crescente de elaboração e aprofundamento. É premissa compreender o universo histórico e social da Dança composto por saberes e fazeres em interlocução com formas de expressão e concepções estéticas locais, nacionais e internacionais, do passado e do presente, perpassando também o diálogo com as outras Artes, com o fazer poético e o pensamento estético. Para que os direitos de aprendizagem da Dança sejam garantidos, é essencial que ocorra a sistematização de processos ao longo da escolarização, espaços escolares adequados para o ensino da Dança e a compreensão da necessidade de formação acadêmica específica para o trabalho com esse componente curricular. (FAEB, 2015, p. 2)

Nós, professores e professoras dos cursos de Artes Cênicas, Licenciaturas em Teatro e Licenciaturas em Dança, abaixo-assinados, solicitamos medidas concretas que garantam o cumprimento da Lei de Diretrizes e Bases da Educação de 1996, que estabelece que o ensino da Arte constitui "componente curricular obrigatório, nos diversos níveis da educação básica (BRASIL, 1996, Art. 26, § 2º). Da mesma forma, manifestamos nossa indignação com o fato de ainda se realizarem concursos públicos e seleções docentes ignorando o que garante a referida LDB. [...] Na trajetória histórica do ensino de Artes no Brasil, uma quantidade significativa de leis, decretos e resoluções têm sido emitidos, enfatizando a sua importância como disciplina que deve integrar o currículo de todas as séries da Educação Básica. Após a LDB de1996, a Lei no 2.287, de 13 de julho de 2010, passa a garantir ainda: " $§ 2^{\circ} \mathrm{O}$ ensino da arte, especialmente em suas expressões regionais, constituirá componente curricular obrigatório nos diversos níveis da educação básica, de forma a promover o desenvolvimento cultural dos alunos". (ABRACE, 2016)

Nota-se o empenho das associações em pensar um ensino de Artes que seja reconhecido como área de conhecimento e não como apêndice para outros componentes curriculares da educação básica, além de garantir que a Lei seja cumprida quando diz respeito a essa linguagem da Arte, bem como as demais linguagens que compõem o componente de Artes na escola.

Outras entidades como o Fórum de Dança de Goiânia, Universidade do Brasil/UFRJ, UNICAMP/Graduações de Dança, dentre outros, manifestaram cartas de solicitação de esclarecimentos, repúdio e inserções no documento da BNCC no que diz respeito à Dança como linguagem e área de conhecimento. Seguem alguns excertos dessas cartas:

VIEIRA, Marcilio de Souza. A arte/dança como uma das artes da cena nas bases, documentos e currículos nacionais. Revista da FUNDARTE, Montenegro, p.175-200, ano 19, no 37, Janeiro/Março. Disponível em: http://.seer.fundarte.rs.gov.br/index.php/RevistadaFundarte/index> 30 de março de 2019 


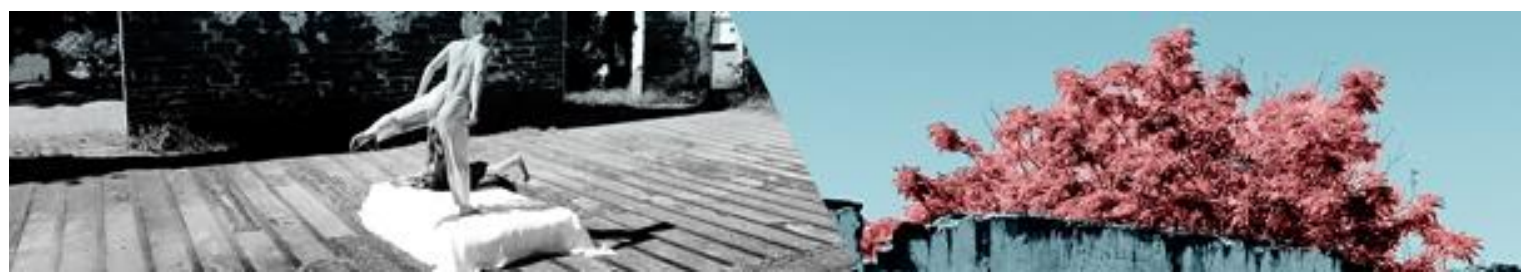

Carta Aberta dos Professores dos Cursos de Graduação em Dança da UFRJ sobre a Base Nacional Comum Curricular e a Especificidade da Dança na Educação Básica.

Senhor Ministro,

Vimos solicitar que, na Base Nacional Comum Curricular (BNCC), os conteúdos pedagógicos relacionados à Dança estejam inseridos no componente "Dança" e não na "Educação Física". Também acreditamos que as interpretações do Ministério da Educação (MEC) sobre o ensino da Dança e das demais artes na Educação Básica, assim como as legislações vigentes, precisam avançar no sentido de sua inserção no currículo de forma autônoma e não como uma subcategoria ou sublinguagem. Da mesma maneira, precisamos avançar na concepção do pensamento de Dança na Educação Brasileira. [...] Nossas contribuições sobre o componente Dança têm a ver com o pensamento de dança, mais especificamente, com pensamento da Dança na Educação que está escrito na organização estrutural do BNCC. Portanto, não podemos nos restringir a responder se concordamos ou não com tais formulações dentro da estrutura já pré-definida. [...] Destarte, e na medida em que as instituições de ensino com substancial histórico na formação em Dança no país não foram consultadas pelo MEC para a elaboração da Base Nacional Comum Curricular, o corpo docente do Departamento de Arte Corporal (DAC) da Escola de Educação Física e Desportos (EEFD) da Universidade Federal do Rio de Janeiro (UFRJ) resolve apresentar este documento com vista a uma elucidação e reiteração da especificidade e complexidade da Dança como campo de conhecimento e atuação. [...] O presente documento faz coro aos demais elaborados pelas Instituições de Ensino Superior em Dança do Brasil e pelo Fórum Nacional de Dança enviados como resposta à consulta pública da BNCC, que exigem que a Dança seja abordada como campo de estudo e aprofundamento exclusivamente pela própria Dança.

Saudações acadêmicas.

(CARTA ABERTA DOS PROFESSORES DOS CURSOS DE GRADUAÇÃO EM DANÇA DA UFRJ, Rio de Janeiro, 13 de Outubro de 2015)

À dança o que é da dança! À Arte o que é da Arte!

Em 2015, o curso de graduação em dança (Departamento de Artes Corporais), composto de bacharelado e licenciatura, comemora 30 anos de existência, na UNICAMP, Universidade de Campinas.

Ao longo desses 30 anos formou profissionais e professores na arte da dança, em sucessivas turmas, cujos alunos falam por si, através do importante trabalho que realizam como artistas e educadores, no Brasil e exterior, atestando a seriedade do ensino aqui praticado. [...] Num pais em que a dança é parte integrante (e essencial) de um tecido cultural de riqueza artística sem precedentes, os formados nos cursos de dança ocupam (e devem seguir ocupando) um lugar fundamental no trabalho que realizam como artistas e educadores, no Brasil e exterior, atestando a seriedade do ensino aqui praticado. [...] Num pais em que a dança é parte integrante (e essencial) de um tecido cultural de riqueza artística sem precedentes, os formados nos cursos de dança ocupam (e devem seguir ocupando) um lugar fundamental no trabalho de formação em arte em suas relações com a cultura, em sentido amplo, atuando, de maneira crescente, em escolas de todo o território nacional. Ensinar a dançar- e toda a espécie de danças-, a partir de pressupostos artísticos - metodológicos, técnicos, científicos e epistemológicos- é o que os egressos destas licenciaturas

VIEIRA, Marcilio de Souza. A arte/dança como uma das artes da cena nas bases, documentos e currículos nacionais. Revista da FUNDARTE, Montenegro, p.175-200, ano 19, ํㅜ 37, Janeiro/Março. Disponível em: http://.seer.fundarte.rs.gov.br/index.php/RevistadaFundarte/index> 30 de março de 2019 


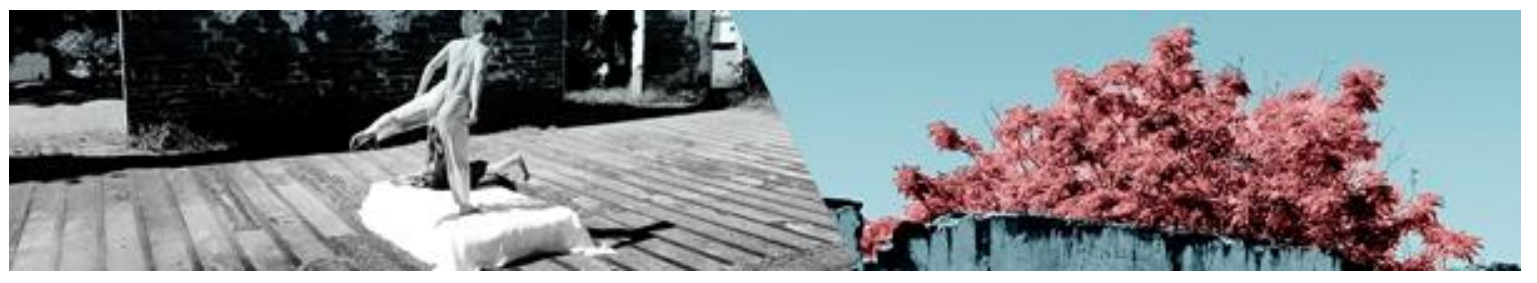

fazem. [...] Por este breve relato, nos causa estranheza que, na atual proposta da base nacional comum curricular, competências específicas da arte da dança e do seu ensino sigam constando da área da educação física, e como competências desta área, apesar de sucessivas mudanças sugeridas pelos especialistas em arte que nesta empreitada trabalham. [...] Não se trata de uma contenda fútil, [...] e sim da busca de um real alinhamento de competências da dança dentro do que ora se constrói para todo o ensino brasileiro na proposta da "Base Nacional Comum Curricular". (CARTA ABERTA DA GRADUAÇÃO EM DANÇA UNICAMP, Campinas,13 de novembro de 2015)

O Fórum de Dança de Goiânia vem, por meio desta, contribuir com o debate sobre o documento preliminar para a criação da Base Nacional Comum Curricular (BNCC). O documento provocou esse Fórum a uma profunda reflexão sobre a importância da dança na escola e, consequentemente, à formação de professores de dança. A nossa escolha por esta carta é compor, dialogar e contribuir com a discussão, apresentando reflexões críticas sobre a própria área, no sentido de fortalecer a dança tanto no campo da expressão artística quanto na educação básica. Acreditamos que o debate crítico e plural é fundamental para potencializar as várias e diferentes vozes, os diversos contextos históricos, políticos, educacionais e artísticos, mas privilegiando aqui a valorização da dança na educação brasileira. [...] Sobre a área de Artes, vale ressaltar que identificamos como desrespeito à luta política e às conquistas já alcançadas pela área no campo da escola, na perspectiva da garantia da especificidade e da autonomia das linguagens artísticas, quando apresenta-se no documento as áreas de conhecimento como subcomponentes do componente curricular Arte. Há uma contradição explicita, pois, o próprio documento afirma que cada linguagem possui seu próprio objeto, estatuto e contexto constituindose como campo que tem singularidades e exige abordagens específicas e especializadas, ou seja, formações específicas, e também cita a Lei $11.769 / 2008$ e o Projeto de Lei 7032/2010 que conduzem para a obrigatoriedade do ensino da Dança, Música, Teatro e Arte Visuais. E, ao considerar que as linguagens possuem licenciaturas específicas, aponta ser necessário um professor habilitado para cada um dos "subcomponentes". Sendo assim, o que justifica essas linguagens serem apresentadas como subcomponentes e não como componentes específicos? No que acarreta ser um subcomponente? Quais as consequências reais de tal propositura? (CARTA DO FÓRUM DE DANÇA DE GOIÂNIA, Novembro de 2015)

Mas, apesar das cartas, dos apontamentos levantados e das discussões em torno do ensino de Artes nos anos iniciais e finais do Ensino Fundamental, tal área de conhecimento ficou relegada à unidade temática, como bem elucidado nesse texto, favorecendo um ensino polivalente dessa área de conhecimento. Observa-se que o exposto na BNCC para as Artes está pautado num modelo de currículo regulado no conteúdo, na avaliação e na gestão. Mesmo assim, é com essas orientações para o ensino de Artes/Dança postulados na BNCC que os professores de Dança devem seguir para que se "tenha" um currículo unificado no país

VIEIRA, Marcilio de Souza. A arte/dança como uma das artes da cena nas bases, documentos e currículos nacionais. Revista da FUNDARTE, Montenegro, p.175-200, ano 19, no 37, Janeiro/Março. Disponível em: http://.seer.fundarte.rs.gov.br/index.php/RevistadaFundarte/index> 30 de março de 2019 


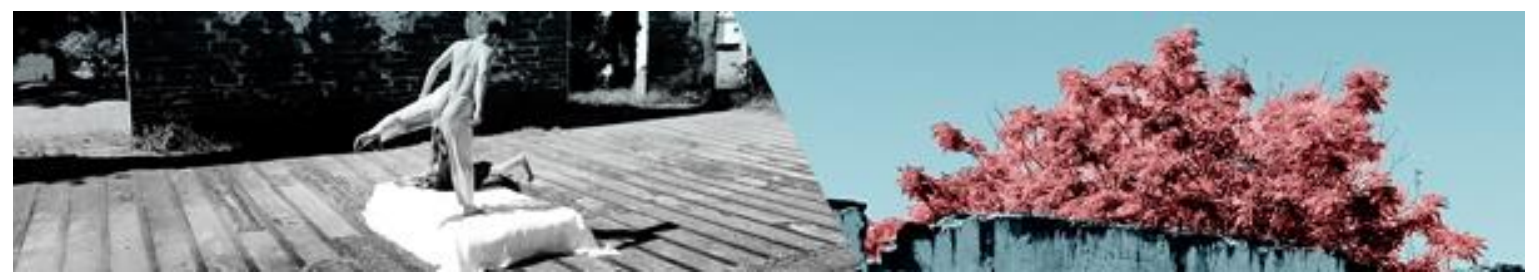

respeitando-se a cultura como "[...] o reconhecimento de semelhanças e diferenças entre elas" (Brasil, 2017, p. 151).

Essa segunda etapa da educação básica é a mais longa e se divide em anos iniciais e finais. De acordo com a BNCC (Idem, p. 53), essa primeira parte do Ensino Fundamental deve "[...] valorizar as situações lúdicas de aprendizagem; aponta para a necessária articulação com as experiências vivenciadas na Educação Infantil”; enquanto que a segunda parte os alunos se deparam com desafios de maior complexidade, fortalecendo sua autonomia, e "[...] é importante, nos vários componentes curriculares, retomar e ressignificar as aprendizagens do Ensino Fundamental - Anos Iniciais no contexto das diferentes áreas, visando ao aprofundamento e à ampliação de repertórios dos estudantes"(Ibidem, p. 56).

Dessa maneira, a progressão do conhecimento ocorre pela consolidação das aprendizagens anteriores, pela ampliação das práticas de linguagem e da experiência estética e intercultural das crianças, considerando tanto seus interesses e expectativas quanto o que ainda precisam aprender além de um percurso contínuo de aprendizagens entre as duas fases do Ensino Fundamental, de modo a promover uma maior integração entre essas fases para que se garanta uma evolução desse processo de educação sem que haja uma ruptura no processo de aprendizagem.

Com relação ao ensino de Artes nessa segunda etapa da educação básica, a BNCC (Ibidem, 2017) apregoa que a aprendizagem de Arte precisa alcançar a experiência e a vivência artísticas como prática social, permitindo que os alunos sejam protagonistas e criadores, e propõe que esses conhecimentos se articulem com as seis dimensões do conhecimento, quais sejam: criação, crítica, estesia, expressão, fruição e reflexão.

No que concerne à linguagem da Dança, a BNCC diz que:

A Dança se constitui como prática artística pelo pensamento e sentimento do corpo, mediante a articulação dos processos cognitivos e das experiências sensíveis implicados no movimento dançado. Os processos de investigação e produção artística da dança centram-se naquilo que ocorre no e pelo corpo, discutindo e significando relações entre corporeidade e produção estética.

Ao articular os aspectos sensíveis, epistemológicos e formais do movimento dançado ao seu próprio contexto, os alunos problematizam e transformam

VIEIRA, Marcilio de Souza. A arte/dança como uma das artes da cena nas bases, documentos e currículos nacionais. Revista da FUNDARTE, Montenegro, p.175-200, ano 19, no 37, Janeiro/Março. Disponível em: http://.seer.fundarte.rs.gov.br/index.php/RevistadaFundarte/index> 30 de março de 2019 


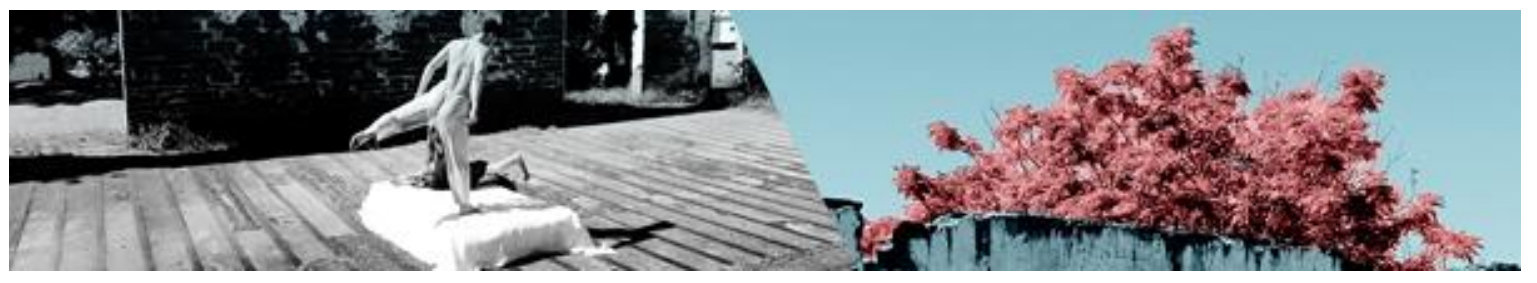

percepções acerca do corpo e da dança, por meio de arranjos que permitem novas visões de si e do mundo. Eles têm, assim, a oportunidade de repensar dualidades e binômios (corpo versus mente, popular versus erudito, teoria versus prática), em favor de um conjunto híbrido e dinâmico de práticas. (Brasil, 2017, p. 153).

Tal linguagem, assim como as outras, deve ser considerada em suas especificidades, mas que possa dialogar com as demais linguagens construindo uma rede de interlocuções, inclusive com outros componentes curriculares.

A BNCC coloca, ainda, uma outra unidade temática denominada de Artes Integradas, que ao nosso ver torna o ensino de qualquer outra unidade temática (Dança, Teatro, Artes Visuais e Música) no âmbito da polivalência, se as secretarias de educação municipal ou estadual, além das escolas particulares de ensino, não articularem esses conhecimentos em suas transversalidades com as linguagens artísticas. Tais "Artes Integradas" são um caminho propício para a polivalência fazendo com que qualquer professor com graduação em uma determinada área de conhecimento da Arte possa ensinar, na escola de educação básica, conteúdos que sejam inerentes a uma determinada linguagem artística.

Nesse caminho de conhecimento marginal, se faz necessária a reflexão da carta dos professores de Dança dos cursos de Licenciatura e Bacharelado da Unicamp, quando indagam À dança o que é da dança! À Arte o que é da Arte!, ou quando os professores do Departamento de Arte Corporal da UFRJ solicitam que os conteúdos pedagógicos relacionados à Dança estejam inseridos no componente "Dança" e não na "Educação Física", ou, ainda, quando o Fórum de Dança de Goiânia afirma, em sua carta, que há uma contradição explicita na BNCC, pois o próprio documento assegura que cada linguagem possui seu próprio objeto, estatuto e contexto constituindo-se como campo que tem singularidades e exige abordagens específicas e especializadas, ou seja, formações específicas e esse mesmo documento, a BNCC em sua terceira versão, postula uma outra unidade temática que articula todo conhecimento da Arte em um único bojo, fazendo-se com que esse componente curricular retroaja ao que preconizava a ditadura militar e a LDB de 1971.

VIEIRA, Marcilio de Souza. A arte/dança como uma das artes da cena nas bases, documentos e currículos nacionais. Revista da FUNDARTE, Montenegro, p.175-200, ano 19, oㅜ 37, Janeiro/Março. Disponível em: http://.seer.fundarte.rs.gov.br/index.php/RevistadaFundarte/index> 30 de março de 2019 


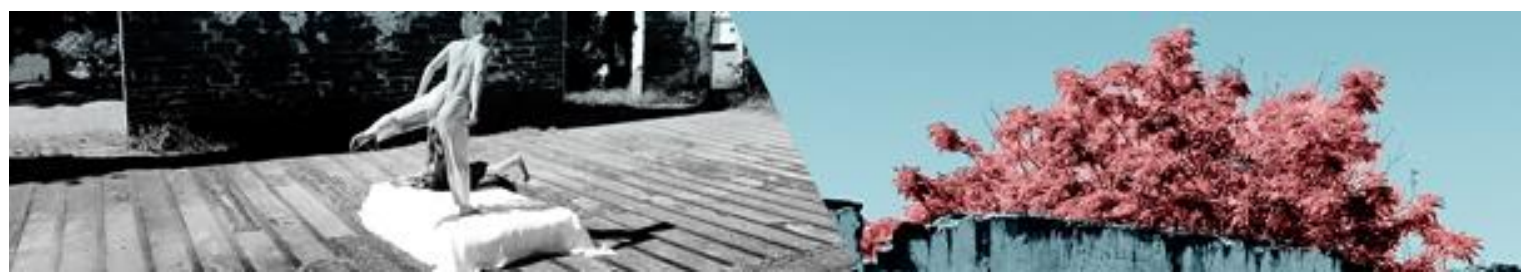

Apesar dessa unidade temática "Artes Integradas", a BNCC aponta os objetos de conhecimento e habilidades para o ensino de Artes/Dança, quais sejam:

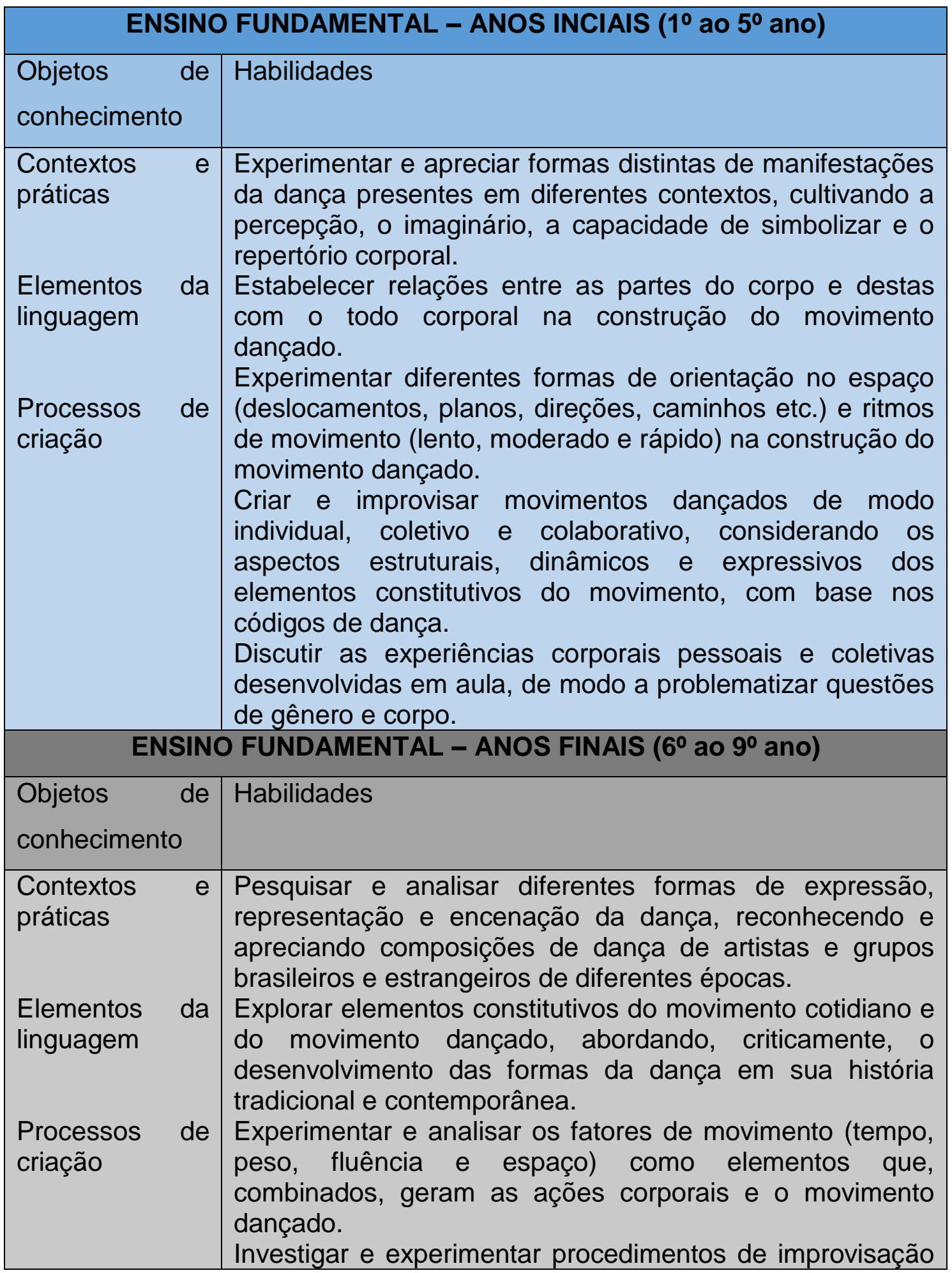

VIEIRA, Marcilio de Souza. A arte/dança como uma das artes da cena nas bases, documentos e currículos nacionais. Revista da FUNDARTE, Montenegro, p.175-200, ano 19, no 37, Janeiro/Março. Disponível em: http://.seer.fundarte.rs.gov.br/index.php/RevistadaFundarte/index> 30 de março de 2019 


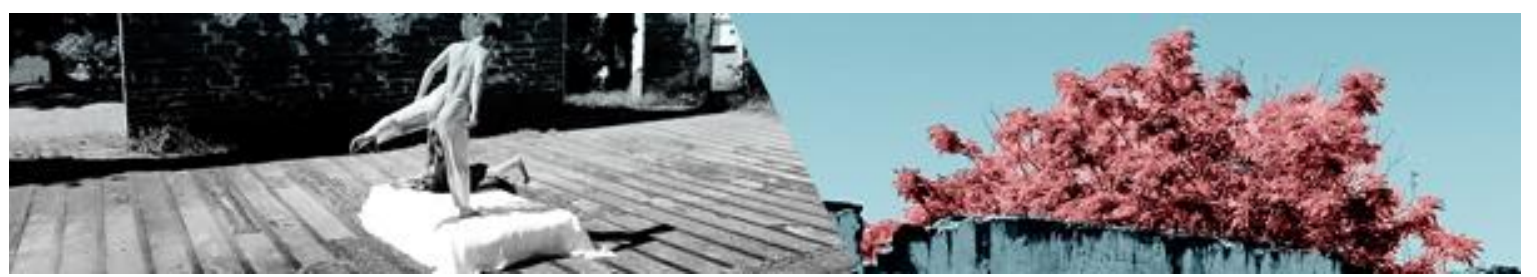

\begin{tabular}{|l|l|}
\hline e criação do movimento como fonte para a construção de \\
vocabulários e repertórios próprios. \\
Investigar brincadeiras, jogos, danças coletivas e outras \\
práticas de dança de diferentes matrizes estéticas e \\
culturais como referência para a criação e composição de \\
danças autorais, individualmente e em grupo. \\
Analisar e experimentar diferentes elementos (figurino, \\
iluminação, cenário, trilha sonora etc.) e espaços \\
(convencionais e não convencionais) para composição \\
cênica e apresentação coreográfica. \\
Refletir sobre as experiências corporais pessoais e \\
coletivas desenvolvidas em aula ou vivenciadas em outros \\
contextos, de modo a problematizar questões de gênero, \\
corpo e sexualidade.
\end{tabular}

Percebe-se no texto produzido pela BNCC para o ensino de Artes/Dança, uma limitação para os objetos de conhecimento da área, o que nos faz pensar numa fragilidade em relação a área de conhecimento da Dança. Nesses "objetos de conhecimento" o documento não levou em conta conteúdos indispensáveis para o currículo dos anos iniciais do Ensino Fundamental.

A experiência do fazer investigativo em/da Dança restringiu-se a três elementos configurando-se num currículo esvaziado de Dança. Nota-se na BNCC pouca relevância para o ensino da Dança no Ensino Fundamental quando desconsidera os contextos sociais em que a dança está inserida (escolas técnicas de dança, dança na/de rua), que também são lugares de aprendizados da dança com objetivos específicos. O referido documento aponta nessa etapa apenas o fazer como modo de construção da dança, sem diálogo com o fruir, o contextualizar, o apropriar-se, o conectar e o desmontar, elementos importantes para a compreensão da dança na escola. Quando limita os objetos de conhecimento da dança a seu fazer dissociado do apreciar, do contextualizar, do criticar e do apropriar-se, por exemplo, exime as dimensões que o próprio documento coloca como fundamentais para o entendimento da Arte/Dança na escola.

Porpino (2012) diz que a dança no currículo deve fazer parte de um projeto educacional em que considere também as experiências trazidas pelo aluno sobre dança, além de considerar esse indivíduo como produtor desse conhecimento. 


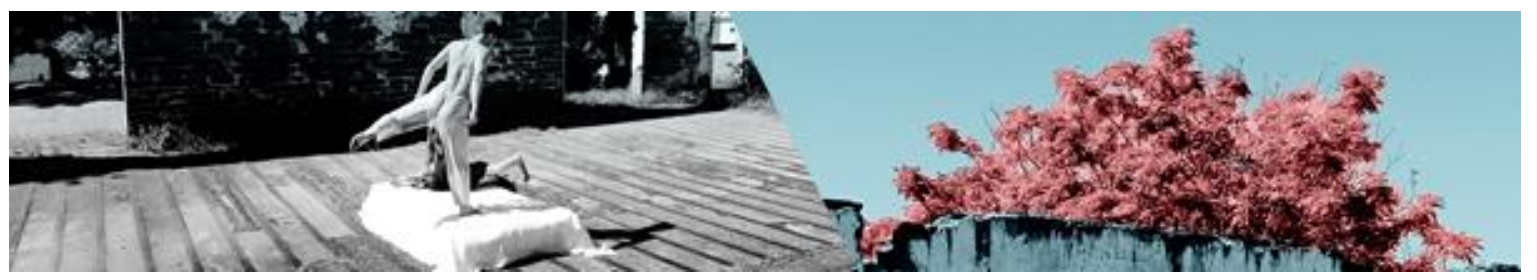

Nesse contexto, é preciso que a escola crie condições para que o aluno se reconheça como indivíduo dançante, a partir da vivência das formas de dançar disponíveis, como também da produção de outras formas de dançar advindas da pesquisa gestual, da apreciação da dança do outro e das possibilidades específicas do contexto vivido. $\mathrm{Na}$ escola, a dança, assim como os outros conteúdos, deve permitir uma visão mais ampliada da realidade social e de como intervir nela criativamente. (Idem, p. 11).

Outros conteúdos ou objetos de conhecimento da dança, além dos já citados na BNCC, são possíveis nessa etapa da educação básica, como: (re)conhecer a forma que se produz a dança em outros lugares além dos espaços escolares; atentar para o conhecimento produzido sobre dança na contemporaneidade; diagnosticar o conhecimento dos alunos sobre a dança, às diversas formas de dançar (técnicas e estéticas das variadas danças da tradição, das danças urbanas e eruditas), os gêneros de dança já produzidos; e dialogar esses conhecimentos com/no corpo (d)o aluno tornando a aprendizagem da dança significativa e que possa pressupor "[...] ações de pesquisa, apreciação, discussão, reflexão, identificação, dentre outras ações que podem complementar, ampliar e contextualizar a vivência gestual da dança" (PORPINO, 2012, p. 13).

Refletir sobre esses objetos de conhecimento possíveis no ensino de Artes/Dança na escola são imprescindíveis para que se tenha um currículo que aponte para o diálogo, que articule conhecimentos produzidos dentro e fora do espaço escolar e que a dança na escola seja, sobretudo, ensinada como conteúdo.

Vimos que a partir da Lei 9.393/96 e de seus desdobramentos em resoluções, decretos, parâmetros e diretrizes, o ensino de Dança foi oportunizado, mesmo que no papel, para o Ensino Fundamental, como pode ser verificado nos parâmetros curriculares e diretrizes nacionais para essa etapa da educação brasileira.

Também foi possível nesse texto traçar apontamentos para as problemáticas reveladas pelos (não) consensos no que diz respeito ao ensino de Artes, em especial a Dança, a partir do que preconiza a BNCC para esse nível de ensino e de como esses consensos/descensos reverberam na sala de aula de Artes da educação básica.

VIEIRA, Marcilio de Souza. A arte/dança como uma das artes da cena nas bases, documentos e currículos nacionais. Revista da FUNDARTE, Montenegro, p.175-200, ano 19, ํㅡ 37, Janeiro/Março. Disponível em: http://.seer.fundarte.rs.gov.br/index.php/RevistadaFundarte/index> 30 de março de 2019 


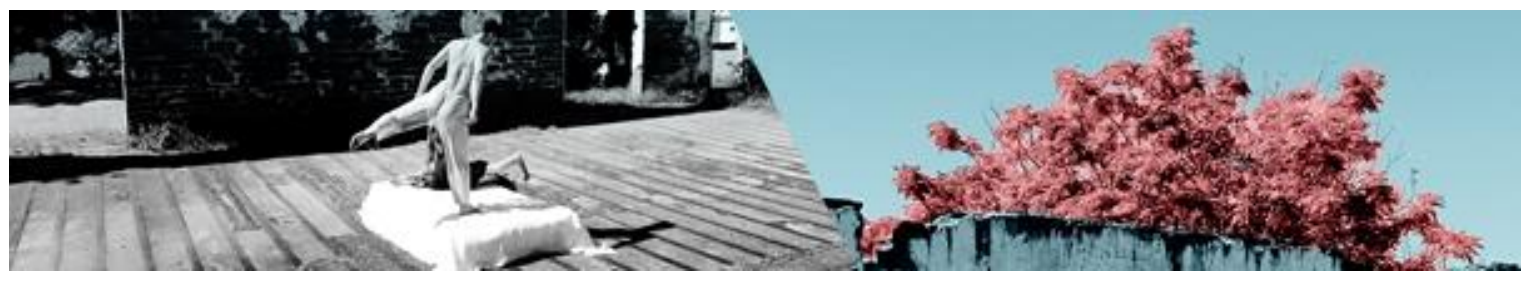

É importante deixar claro que este trabalho não se propôs a esgotar o assunto referente ao ensino de Artes/Dança na educação brasileira. Pretendeu-se apenas refletir parte da formação do processo educacional no Brasil, considerando o ensino de Artes/Dança de suma relevância para a educação brasileira como um todo.

\section{Referências:}

ABRACE. CARTA ABERTA AOS GOVERNOS E GESTORES EDUCACIONAIS DOS DOCENTES DAS LICENCIATURAS EM DANÇA E EM TEATRO DO BRASIL, 2016. http://www.portalabrace.org. Acesso em dezembro de 2017.

BARBOSA, A. M. Arte-educação no Brasil. São Paulo: Perspectiva, 2002.

BRASIL. MINISTÉRIO DA EDUCAÇÃO. Lei no 4024 de 20 de dezembro de 1961. Brasília, DF, 1961.

. Lei de Diretrizes e Bases da Educação Nacional, 1971. Brasília, 1971.

- Parecer $n^{\circ}$ 540/1977, do CFE sobre o tratamento a ser dado aos componentes curriculares previsto no Artigo $n^{\circ} 7^{\circ}$ da Lei 5692/71 in documenta $n^{\circ}$ 195, Rio de Janeiro, fev. 1977.

. Constituição da República Federativa do Brasil. Brasília: Senado Federal, 1988.

. MINISTÉRIO DA EDUCAÇÃO E DO DESPORTO. Lei de Diretrizes e Bases da Educação Nacional, Lei no 9394/96. Brasília, 1996.

. CONSELHO NACIONAL DE EDUCAÇÃO. CÂMARA DA EDUCAÇÃO BÁSICA. Resolução CNE/CEB no 2, de 30 de janeiro de 2012. Institui as Diretrizes Curriculares Nacionais para o Ensino Médio. Diário Oficial da União, Brasília, DF, 31 jan. 2012.

MINISTÉRIO DA EDUCAÇÃO/CONSELHO NACIONAL DE EDUCAÇÃO. Parecer CNE/CEB no: 22/2005. Aprova retificação do termo que designa a área de conhecimento "Educação Artística" pela designação "Arte". Brasília, 2005. Disponível em: www.mec.br. Acesso em fevereiro de 2018.

MINISTÉRIO DA EDUCAÇÃO. Base Nacional Comum Curricular. Brasília, 2015. Disponível em: http://basenacionalcomum. mec.gov.br. Acesso em 15 jul. 2017.

VIEIRA, Marcilio de Souza. A arte/dança como uma das artes da cena nas bases, documentos e currículos nacionais. Revista da FUNDARTE, Montenegro, p.175-200, ano 19, no 37, Janeiro/Março. Disponível em: http://.seer.fundarte.rs.gov.br/index.php/RevistadaFundarte/index> 30 de março de 2019 


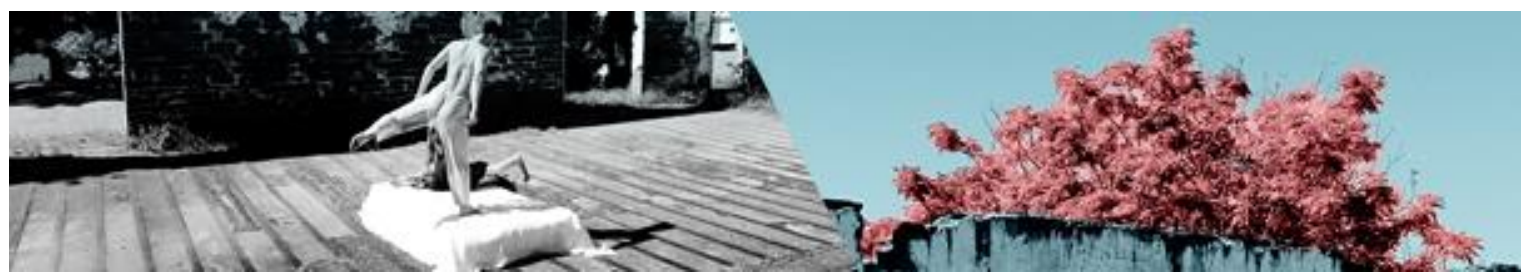

. MINISTÉRIO DA EDUCAÇÃO. Base Nacional Comum Curricular. Brasília, 2016. Disponível em: http://basenacionalcomum. mec.gov.br. Acesso em 15 jul. 2017.

Lei no 13.415 , de 16 de fevereiro de 2017. Altera as Leis nos 9.394 , de 20 de dezembro de 1996, que estabelece as diretrizes e bases da educação nacional, e 11.494, de 20 de junho 2007, que regulamenta o Fundo de Manutenção e Desenvolvimento da Educação Básica e de Valorização dos Profissionais da Educação. Brasília, 2017.

CORRÊA, C. C. M. Atitudes e valores no ensino da arte: após a lei no 4.024/61 até a atual lei de diretrizes e bases da educação nacional - lei no 9.394/96. EccoS Revista Científica, São Paulo, v. 9, n. 1, p. 97-113, jan./jun. 2007.

FAEB. Ofício no 06/2015/FAEB. Análise do componente ARTE da Base Nacional Comum Curricular aberta à consulta pública. Ponta Grossa, 30 de novembro de 2015. Disponível em: http://www.faeb.com.br. Acesso em 20/02/2018.

FÓRUM DE DANÇA DE GOIÂNIA. Carta do fórum de dança de Goiânia. Goiânia, novembro de 2015.2 Disponível em http://portalabrace.org/c2/index.php/informeseboletins. Acesso em 20/02/2018.

FUSARI, M. F. R.; FERRAZ, M. H. C. T. A arte na educação escolar. São Paulo: Cortez, 2001.

PORPINO, K. O. Dança e currículo. In: Salto para o futuro. Dança na escola: arte e ensino. Ano XXII, boletim 2, abr. 2012.

VIEIRA, M. S. A dança na arte e na educação física: diálogos possíveis. Revista Tempos e Espaços em Educação, v. 13, p. 177-185, 2014. currículos nacionais. Revista da FUNDARTE, Montenegro, p.175-200, ano 19, no 37, Janeiro/Março. Disponível em: http://.seer.fundarte.rs.gov.br/index.php/RevistadaFundarte/index> 30 de março de 2019 